\title{
REVIEW
}

\section{Antarctic krill Euphausia superba: spatial distribution, abundance, and management of fisheries in a changing climate}

\author{
Margaret M. McBride ${ }^{1, *}$, Olav Schram Stokke ${ }^{2,3}$, Angelika H. H. Renner ${ }^{1}$, \\ Bjørn A. Krafft ${ }^{1}$, Odd A. Bergstad ${ }^{1}$, Martin Biuw ${ }^{1}$, Andrew D. Lowther ${ }^{4}$, Jan E. Stiansen ${ }^{1}$ \\ ${ }^{1}$ Institute of Marine Research, PO Box 1870 Nordnes, 5817 Bergen, Norway \\ ${ }^{2}$ University of Oslo, Department of Political Science, 0317 Oslo, Norway \\ ${ }^{3}$ Fridtjof Nansen Institute, 1326 Lysaker, Norway \\ ${ }^{4}$ Norwegian Polar Institute, PO Box 6606 Langnes, 9296 Tromsø, Norway
}

\begin{abstract}
Antarctic krill Euphausia superba, a keystone species in the Southern Ocean, is highly relevant for studying effects of climate-related shifts on management systems. Krill provides a key link between primary producers and higher trophic levels and supports the largest regional fishery. Any major perturbation in the krill population would have severe ecological and economic ramifications. We review the literature to determine how climate change, in concert with other environmental changes, alters krill habitat, affects spatial distribution/abundance, and impacts fisheries management. Findings recently reported on the effects of climate change on krill distribution and abundance are inconsistent, however, raising questions regarding methods used to detect changes in density and biomass. One recent study reported a sharp decline in krill densities near their northern limit, accompanied by a poleward contraction in distribution in the Southwest Atlantic sector. Another recent study found no evidence of long-term decline in krill density or biomass and reported no evidence of a poleward shift in distribution. Moreover, with predicted decreases in phytoplankton production, vertical foraging migrations to the seabed may become more frequent, also impacting krill production and harvesting. Potentially cumulative impacts of climate change further compound the management challenge faced by CCAMLR, the organization responsible for conservation of Antarctic marine living resources: to detect changes in the abundance, distribution, and reproductive performance of krill and krill-dependent predator stocks and to respond to such change by adjusting its conservation measures. Based on CCAMLR reports and documents, we review the institutional framework, outline how climate change has been addressed within this organization, and examine the prospects for further advances toward ecosystem risk assessment and an adaptive management system.
\end{abstract}

KEY WORDS: Antarctic krill · Climate change $\cdot$ Ecosystem $\cdot$ Distribution $\cdot$ Abundance $\cdot$ Food web · Management $\cdot$ CCAMLR $\cdot$ Commission for the Conservation of Antarctic Marine Living Resources

\section{INTRODUCTION}

The Southern Ocean is a region of high physical and biological variability (Hempel 1985, Constable et al. 2003). Its diverse biota, adapted to extreme envi-

\footnotetext{
${ }^{*}$ Corresponding author: margaret.mcbride@hi.no
}

ronmental conditions, respond quickly to ecosystem perturbations (Flores et al. 2012a, Rintoul et al. 2012, De Broyer et al. 2014, McBride et al. 2014). Climate change may affect organisms and populations physiologically and by altering their habitats. Understand-

(C) The authors and Research Council of Norway 2021. Open Access under Creative Commons by Attribution Licence. Use, distribution and reproduction are unrestricted. Authors and original publication must be credited.

Publisher: Inter-Research · www.int-res.com 
ing these habitat effects facilitates understanding the effects on biological variables such as population distribution, abundance and movement patterns, and biomass production. Possible shifts in the distribution of commercially harvested Antarctic krill Euphausia superba (henceforth krill) populations in response to climate variability present a key challenge to effective management.

The Commission for the Conservation of Antarctic Marine Living Resources (CCAMLR) has established precautionary catch limits on the krill fishery in most of the areas where fishing has occurred, but these catch limits apply to large statistical subareas. It is now 3 decades since the CCAMLR stated its ambition to advance from a precautionary approach to a feedback management system capable of continuously adjusting krill conservation measures in response to new knowledge on krill stocks and associated species (CCAMLR 1991a). However, monitoring of krill stocks and krill-dependent species has been too limited to provide a satisfactory knowledge base to assess the level of risk associated with krill fisheries and respond quickly to changing indices of ecosystem components - including updated, lifecyclesensitive, and spatially relevant information on krill distribution, abundance, flux, and trophic interactions (Krafft et al. 2015, 2018, BAS 2018, Santa Cruz et al. 2018). CCAMLR has recognized the need for revision of current management approaches as urgent (CM 51-07-2016; CCAMLR 2016b).

This review seeks to answer 2 main questions: (1) What are the potential cumulative effects of climate change on the distribution and abundance of Antarctic krill? (2) What are the prospects for changing



Fig. 1. Pelagic female Antarctic krill feeding on summer phytoplankton. Adults range from 5.0 to $6.5 \mathrm{~cm}$ in length and weigh an average of $2 \mathrm{~g}$. Adult females are slightly larger than adult males. Image () V. Siegel, Thünen Institut für Seefischerei, Hamburg, used with permission
CCAMLR's approach to krill fisheries management to accommodate ongoing and future climate-related changes in the stock? We synthesize the results of studies published in peer-reviewed journals to provide an overview of changes in the physical and biological environment and examine how these changes affect the distribution and abundance of krill. Based on CCAMLR reports and documents, we examine how climate change has been addressed within this organization, with an emphasis on its ecosystem-based risk assessment of krill fisheries and its advances toward a feedback management system capable of responding to climate variability.

\section{KRILL BIOLOGY AND PHYSICAL ENVIRONMENT}

\subsection{Biology}

Antarctic krill (Fig. 1, Table 1) is a large (up to $65 \mathrm{~mm}$ ), long-lived (5-7 yr lifecycle) euphausiid species that is abundant, widely distributed, and ecologically important in the Southern Ocean. It can form large swarms, sometimes reaching densities of $10000-$ 30000 ind. $\mathrm{m}^{-3}$ (Hamner et al. 1983). Its biology and ecology have been reviewed many times: in multiauthored publications (e.g. Everson 2000, Siegel 2016); in numerous scientific publications (e.g. Bargmann 1945, Marr 1962, Cuzin-Roudy \& Amsler 1991, Atkinson et al. 2004, 2008, 2019, Kawaguchi \& Nicol 2007, 2020, Siegel \& Watkins 2016, Cox et al. 2018); and as a popular science book (Nicol 2018). Rather than repeat what has already been reported, this section focuses on aspects of krill biology which make it vulnerable to climate-related changes in its physical environment.

Antarctic krill is a cold-adapted stenothermic species mainly inhabiting waters $<3.5^{\circ} \mathrm{C}$; sudden water temperature changes might impact its physiological performance and behavior (Daly 1998, Flores et al. 2012a, Krafft \& Krag 2015). During the course of its complicated life cycle, krill inhabits benthic, surface, and pelagic environments structured by sea-ice extent and concentration, water temperatures, and circulation patterns (Nicol 2006, Nicol \& Raymond 2012). Its annual and lifecycle phases occur in close association with sea ice, where it feeds on ice algae and finds shelter from predators (Quetin \& Ross 2001, Brierley et al. 2002, Smetacek \& Nicol 2005) (Fig. 2).

Piñones \& Fedorov (2016) identified 3 critical periods of the krill early lifecycle during which environmental conditions exert a dominant control over survival: (1) development of larvae into the first feeding 
Table 1. Biological characteristics of Antarctic krill living in the Southern Ocean south of the Antarctic Polar Front (adapted from: De Broyer et al. 2014)

\begin{tabular}{|lcc|}
\hline Biological characteristic & Reported observation & References \\
\hline Vertical depth range $(\mathrm{m})$ & Surface to 3000 & Taki et al. (2008) \\
Temperature range $\left({ }^{\circ} \mathrm{C}\right)$ & -1.8 to 5 & Ross et al. (2000), Schmidt et al. (2014) \\
Swarming behavior & + & Ross \& Quetin (2000) \\
Vertical migration & + & Taki et al. (2008) \\
Adult size (mm) & 65 & Ross \& Quetin (2000) \\
Adult weight (g) & 2 & Ross \& Quetin (2000) \\
Lifespan (yr) & $5-7$ & Siegel (1987), Ross \& Quetin (2000) \\
Spawning period (cycles) & December-April (1 to 3) & Mauchline (1980), Ross \& Quetin (2000) \\
Diet (adults) & Phytoplankton (diatoms, flagellates), & Mauchline \& Fisher (1969), Phleger et al. (2002) \\
Predators & zooplankton (copepods), detritus & Nemoto et al. (1985), Murphy et al. (2016) \\
\hline
\end{tabular}

stage at the end of austral summer; (2) accumulation of sufficient lipid reserves during late summer and fall, allowed by food availability; and (3) enduring the first winter, when under-sea ice habitat provides both food (algae) and shelter (Fig. 2). Temperature and depth of Circumpolar Deep Water control success of the descent-ascent phase of the krill reproductive cycle (Quetin \& Ross 1984, Hofmann \& Hüsrevoğlu 2003); temperature also moderates the extent of sea ice (Daly 1990, Ross \& Quetin 1991, Meyer et al. 2002).

The winter under-ice population is dominated by larvae and juvenile krill feeding on the available ice algae. Consequently, sea-ice retreat, particularly in winter, can become a dominant driver of krill population decline (Flores et al. 2012a,b, Piñones \& Fedorov
2016). Projected reduction in sea-ice coverage ( 80\% by 2100) may reduce krill spawning grounds in important habitats such as along the west Antarctic Peninsula in the southwest Atlantic sector (Hofmann et al. 1992, Fach et al. 2002, 2006, Thorpe et al. 2004, 2007, Atkinson et al. 2008, Piñones et al. 2013, Piñones \& Fedorov 2016).

\subsection{Physical environment}

Circulation in the Southern Ocean is dominated by the eastward-flowing Antarctic Circumpolar Current (ACC). Closer to the coast, the Antarctic Coastal Current flows westward around the continent. The other

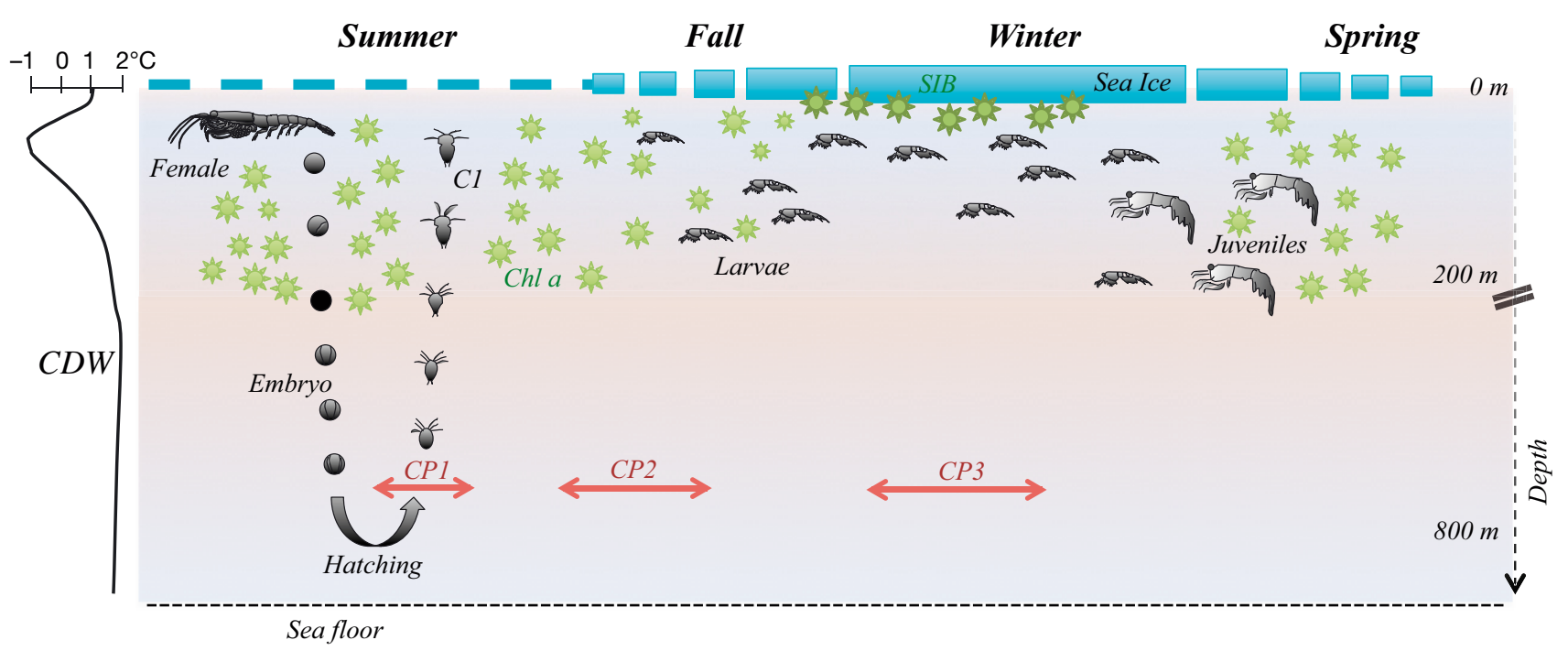

Fig. 2. Antarctic krill early lifecycle. After hatching, embryos develop from nauplii to first feeding stage calyptopis 1 (CP1); after the descent/ascent cycle (CP1), they feed on chlorophyll a (chl a) during summer and early fall. They overwinter underneath sea ice and molt into juveniles in spring. Three critical periods (CP1, -2, and -3) are indicated. SIB: sea-ice biota for winter-feeding by krill larvae. CDW: Circumpolar Deep Water. (Source: modified figure and description used with permission from Piñones \& Fedorov 2016) 


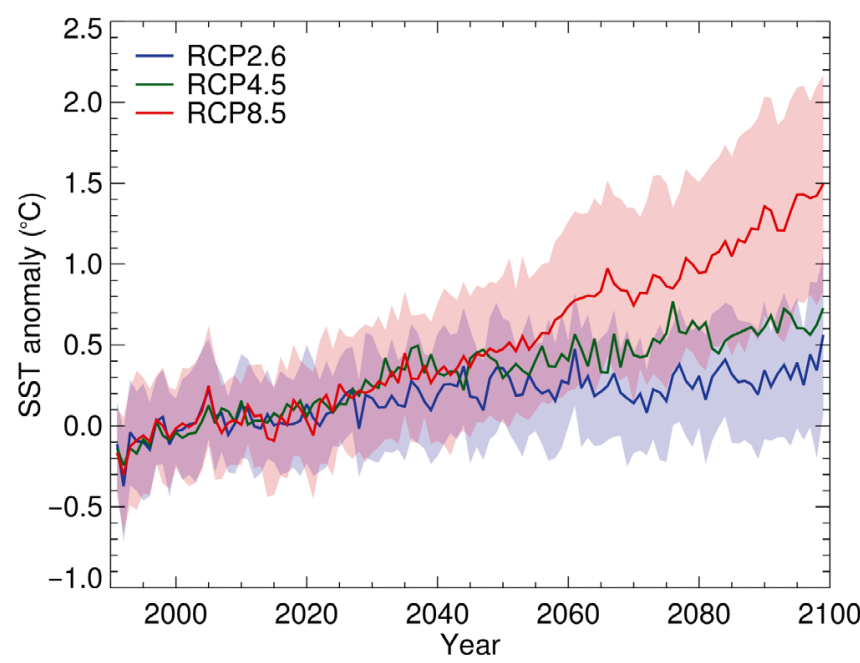

Fig. 3. Projected summer (January to March) sea surface temperature (SST) anomaly for the region between $0^{\circ}$ and $90^{\circ} \mathrm{W}$ and south of the Antarctic Polar Front (Antarctic Convergence). The SST anomaly is the annual mean of spatially resolved summer SSTs for a specific model realization minus the 1991-2020 mean of spatially resolved summer SSTs for the same model realization. The colored lines indicate the mean SST anomaly for 1991-2099 across all available models for each of 3 Representative Concentration Pathways (RCPs), and the shaded envelopes indicate the between-realization standard deviation for RCPs 2.6 and 8.5. (Source: figure and description used with permission from Hill et al. 2013)

major physical feature of this system is the annual advance and retreat of sea ice (Constable et al. 2003). Parts of the Southern Ocean warmed considerably during the second half of the $20^{\text {th }}$ century, with greater temperature increases in some regions than those of the global ocean (Fig. 3) (Levitus et al. 2000, 2005, Gille 2002, 2008, Whitehouse et al. 2008, Schmidtko et al. 2014, Swart et al. 2018).

Particularly the Atlantic sector of the Southern Ocean, where most krill is located, has experienced rapid upper-ocean warming (Meredith \& King 2005, Whitehouse et al. 2008), loss of winter sea ice (Parkinson 2002), and great inter-annual variability in chlorophyll a (chl a) concentrations (Constable et al. 2003). Summer foraging sites for krill in the Atlantic sector have experienced sea surface temperature (SST) increase of up to $0.2^{\circ} \mathrm{C}$ per decade, and projections indicate that further widespread increase of $0.27-1.08^{\circ} \mathrm{C}$ per decade may occur by the late $21^{\text {st }}$ century (Fig. 3) (Hill et al. 2013). This warming trend is not spatially uniform, however; certain parts of the Southern Ocean are cooling (Gille 2008, Schmidtko et al. 2014).

Off the continental shelf, Circumpolar Deep Water has warmed in most regions (Gille 2008, Schmidtko et al. 2014), with similar warming below $2000 \mathrm{~m}$ (Purkey \& Johnson 2012, Desbruyères et al. 2016).
Temperature increase in the Antarctic Bottom Water, together with a freshening (Azaneu et al. 2013, Jullion et al. 2013), has resulted in a contraction of its volume (Purkey \& Johnson 2012, Azaneu et al. 2013). On the shelf, Schmidtko et al. (2014) found a complex pattern of temperature trends in Antarctic Continental Shelf Bottom Water, with regional patterns of warming along most of the Antarctic Peninsula and in the Bellingshausen and Amundsen Seas, and cooling in the southern Weddell Sea.

SST and specific isotherms are often used to identify positions of the ACC front. Following such definitions, observed warming implies a potential poleward shift of the ACC and its fronts (Gille 2008, Cristofari et al. 2018). However, fronts are more complex than their SST expression, and more advanced analyses have not revealed such a shift (Gille 2014, Freeman et al. 2016, Chapman 2017, Chambers 2018). Future projections of ACC strength, meandering, and position involve considerable uncertainty (Meijers et al. 2012, 2019, Meijers 2014). Any such changes in the ACC, as well as changes in ocean temperatures, might influence the volume and stability of Antarctic sea ice (Gille 2002).

By reducing the area of sea-ice formation near the Antarctic Peninsula and other critical regions of the Southern Ocean, climate change is reducing the feeding potential for krill and, consequently, its recruitment and overall production (Walther et al. 2002, Flores et al. 2012a,b). The central role of krill in Southern Ocean food webs makes understanding how climate affects its abundance and distribution a prerequisite for effective management of commercial fisheries. Particularly, the rapid rate of changes underway in the Antarctic marine ecosystem necessitates better predictions of how inter-annual variability in environmental conditions may influence krill production and affect krill-dependent species.

\section{CLIMATE-CHANGE IMPACTS ON SPATIAL DISTRIBUTION AND ABUNDANCE OF KRILL}

After nearly a century of observations, the general patterns of krill occurrence and distribution have been determined. Krill distribution exhibits considerable spatial variability, both inter- and intra-annual, with juveniles and adults forming large swarms (Nicol et al. 2012, Siegel \& Watkins 2016, Ryabov et al. 2017, Atkinson et al. 2019). They perform large horizontal and vertical migrations (from surface to $>3000 \mathrm{~m}$ depth) (Morris et al. 1983, Kawaguchi \& Nicol 2007, De Broyer et al. 2014). However, less is 
known of the precise migration patterns, as much of the Southern Ocean is still poorly sampled. There is concern over possible long-term changes in krill distribution and abundance as a result of climate change and harvesting, and how to distinguish these variables from each other in time and space (Siegel \& Watkins 2016).

Richardson (2008) suggested that mechanisms related to climate change and the retreat of sea ice will primarily impact krill in 3 ways:

(1) Water temperature in correlation with sea ice coverage appears to be the driving factor for krill density (Trathan et al. 2003, Wiedenmann et al. 2008, 2009, Wiedenmann 2010). In warming regions of the Southern Ocean, a negative relationship between increasing surface temperature and krill density has already been observed (Trathan et al. 2003, Atkinson et al. 2019).

(2) There may be changes in the timing of important events in the krill lifecycle (phenology), such as the timing of spawning or hatching (Wiedenmann 2010).

(3) Levels of abundance may change, mediated largely through variable food supply. However, detecting long-term trends in abundance and attributing them to climate variation is more difficult than detecting the changes described above (Wiedenmann 2010).

Other potentially important mechanisms include:

(4) The effect higher temperatures have on individual growth. Krill grow through a series of molts, and both the time between molts and growth increment per molt are inversely temperature-dependent (Quetin et al. 2003, Atkinson et al. 2006, Kawaguchi et al. 2006, Tarling et al. 2006, Wiedenmann 2010, Bellard et al. 2012).

(5) The direct impact of the changing seasonal cycle of light on krill physiological processes, such as initiation of production of oocytes (Spiridonov 1995, Quetin et al. 2007).

\subsection{Impacts on horizontal distribution}

Mackintosh (1973) indicated 5 to 6 krill stocks around the Antarctic continent but suggested that these areas of higher krill density should not be regarded as isolated populations. Latogurski (1979) speculated that krill associated with the 3 main gyre systems around the continent might be regarded as independent populations (Duan et al. 2016, Siegel \& Watkins 2016), but the vast population size and huge genome make it difficult to detect separate krill stocks. Deagle et al. (2015) reported that studies of krill genetic and genomic data had not indicated genetic structuring of krill by sites around Antarctica. In contrast, Clarke et al. (2021) indicated that krill-associated bacterial communities are geographically structured.

The horizontal distribution of krill is affected by advection and retention due to ocean currents, eddies, and sea-ice drift, depending on hydrodynamic forces and stage in the krill lifecycle (Nicol 2006, Mori et al. 2017). Larval and juvenile krill are passively advected by prevailing currents. Although adult krill are strong swimmers, capable of going against the currents, their movements are influenced by the flow regime around individuals and swarms (Tarling \& Thorpe 2014, Reiss et al. 2017). Within a flow regime where surface current speeds can reach up to ca. $100 \mathrm{~cm} \mathrm{~s}^{-1}$ (Smith et al. 2010, Tarling \& Thorpe 2014), individual adult krill can maintain speeds of no more than $15 \mathrm{~cm} \mathrm{~s}^{-1}$ without increasing metabolic rate (Kils 1981); this may limit their capacity to control their location within highly advective environments. Krill swarms sustain speeds of $20 \mathrm{~cm}$ $\mathrm{s}^{-1}$ (Hamner 1984, Tarling \& Thorpe 2014); this may help to maintain swarm coherence in the face of dispersive surface currents (Zhou \& Dorland 2004).

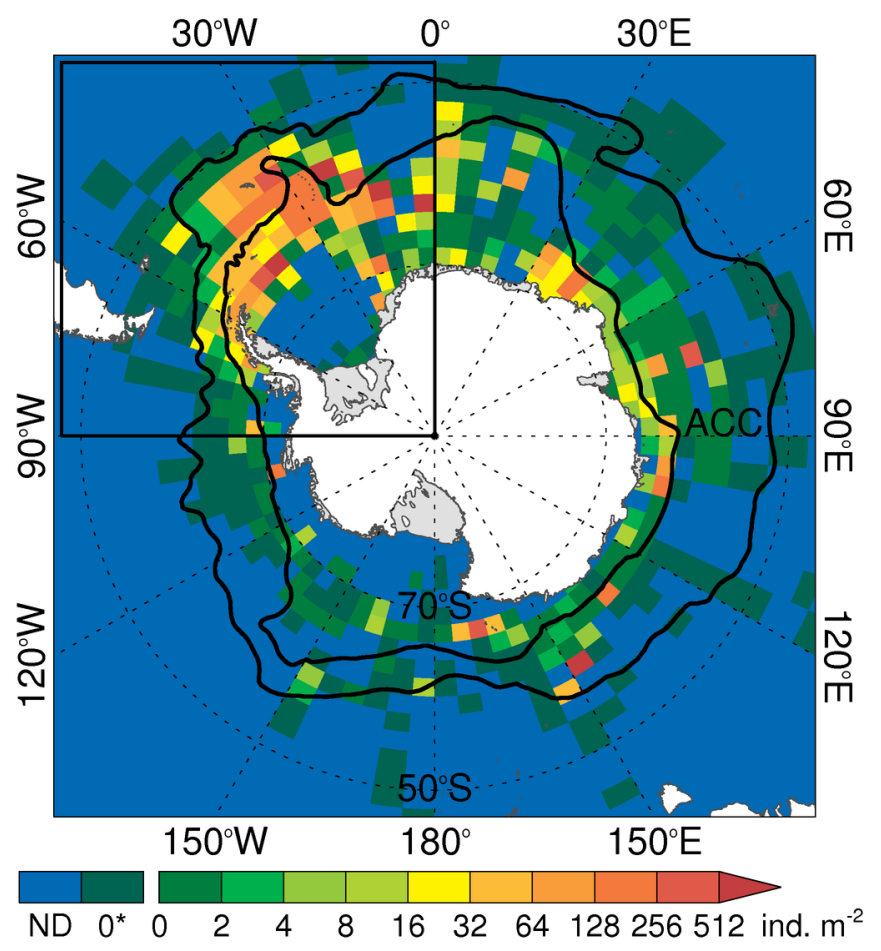

Fig. 4. Observed distribution and concentration of Antarctic krill (ind. $\mathrm{m}^{-2}$ within each $5^{\circ}$ longitude by $2^{\circ}$ latitude grid cell, ND: no data, $0^{*}$ : no Antarctic krill recorded in the available data). (Source: modified figure and description used with permission from Atkinson et al. 2008 and Hill et al. 2013) 


\subsubsection{Ocean warming and habitat quality}

The habitat used by krill comprises more than half of the approximately 32 million $\mathrm{km}^{2}$ area of the entire Southern Ocean south of the Polar Front (Mackintosh 1973, Siegel \& Watkins 2016). The horizontal distribution of krill is uneven, however, with more than half of the circumpolar population occurring in the Atlantic sector (Atkinson et al. 2004) (Fig. 4). The largest concentrations and highest densities (observed and predicted) occur around the Antarctic Peninsula, in the Scotia and Weddell Seas - particularly in the Polar Front zone and the Southern ACC Front - and from the continental coast to the northern limit of the Polar Front in the whole eastern sector (Marr 1962, Atkinson et al. 2004, Nicol 2006, De Broyer et al. 2014, Siegel \& Watkins 2016, Silk et al. 2016). Data from comparable net and acoustic surveys indicate that average krill densities in the South Atlantic may be 10 times higher than off East Antarctica $\left(30-150^{\circ} \mathrm{E}\right)(\mathrm{Nicol}$ et al. $2000 \mathrm{a}$, b, Nicol 2006); this region, with its convoluted coastline and many island groups, offers more suitable habitat for krill (Nicol 2006, Atkinson et al. 2008). Despite high concentrations in the Atlantic sector, the habitat used by krill comprises more than half of the approximately 32 million $\mathrm{km}^{2}$ area of the entire Southern Ocean south of the Polar Front (Mackintosh 1973, Siegel \& Watkins 2016).

The circumpolar distribution of krill has been observed from the continent to the northern limit of the Polar Front, although in most of their range they are far to the south. The only region where krill wasboth observed and predicted to be-absent in the entire Polar Front Zone lies between 60 and $150^{\circ} \mathrm{E}$ (De Broyer et al. 2014). In this region, sea ice retreats almost completely to the coast during summer, and hydrographic conditions are different. Low concentrations of silicates (which do not favor diatom blooms) and climate-induced changes in the mixedlayer depth (which affect both spatial distribution of production and phytoplankton commu nity structure) are likely driving factors behind the reduced occurrence of krill in this region, as the best habitat conditions generally occur near the continental shelf (Flores et al. 2012a).

Suitable krill habitat is linked to various processes - seasonal sea-ice dynamics, frontal zones, and mixing associated with bathymetry (Siegel 2005, Murphy et al. 2007), spring light regime, and supply of critical nutrients like nitrates and iron-supporting the production of chl $a$, an important indicator of the presence and concentration of phytoplankton
(Atkinson et al. 2004). At the physiological level, high phytoplankton concentration can sometimes compensate for the negative effects of temperature (Pörtner 2012). This is demonstrated by elevated krill abundance and favorable growth rates observed at South Georgia. This area is near the northern limit of the species' range; it has relatively high and physiologically stressful temperatures, but also has very high food concentrations (Atkinson et al. 2008). Qualitative analyses of krill habitats have consistently shown that spatio-temporal variability is a common feature of krill populations and that krill habitat cannot be simply described using a small number of variables (Jarvis et al. 2010, O'Brien et al. 2011, Young et al. 2014).

Diatom blooms provide an essential food for the lipid metabolism of krill (Mayzaud et al. 1998): energy transfer from these spring phytoplankton blooms is essential for sexual differentiation in gonads during the late furcilia phase of larval development (CuzinRoudy 1987a,b); maturation into adulthood, the onset of successive reproductive cycles during summer (Cuzin-Roudy 1993, 2000); and maintaining high fecundity during summer (Cuzin-Roudy \& Labat 1992, Ross \& Quetin 2000).

Employing models that explicitly include the interacting ecological effects of temperature and food availability is a useful step towards fuller consideration of the multiple interacting effects of climate change on the abundance and distribution of krill (Stock et al. 2011, Pörtner 2012, Hill et al. 2013).

\subsubsection{Poleward shift}

Modeling studies to predict the fate of krill under different warming scenarios seem to be in general agreement, forecasting both a reduction and a poleward shift of the available krill habitat for spawning and growth (Hofmann et al. 1992, Hill et al. 2013, Cuzin-Roudy et al. 2014, CCAMLR 2015, Piñones \& Fedorov 2016). The Cuzin-Roudy et al. (2014) model of habitat suitability explained $63 \%$ of variance and has been used to infer the presence of krill in regions where sampling data are limited (Fig. 5). The results show high probability of occurrence almost everywhere south of the Polar Front, and low probability north of it (Cuzin-Roudy et al. 2014). Habitat modeling also indicates that, at high latitudes, horizontal distribution and spawning may extend to areas of suitable habitat where krill has not been observed in the past, including in the Indian Ocean and Pacific sectors (Atkinson et al. 2008). 


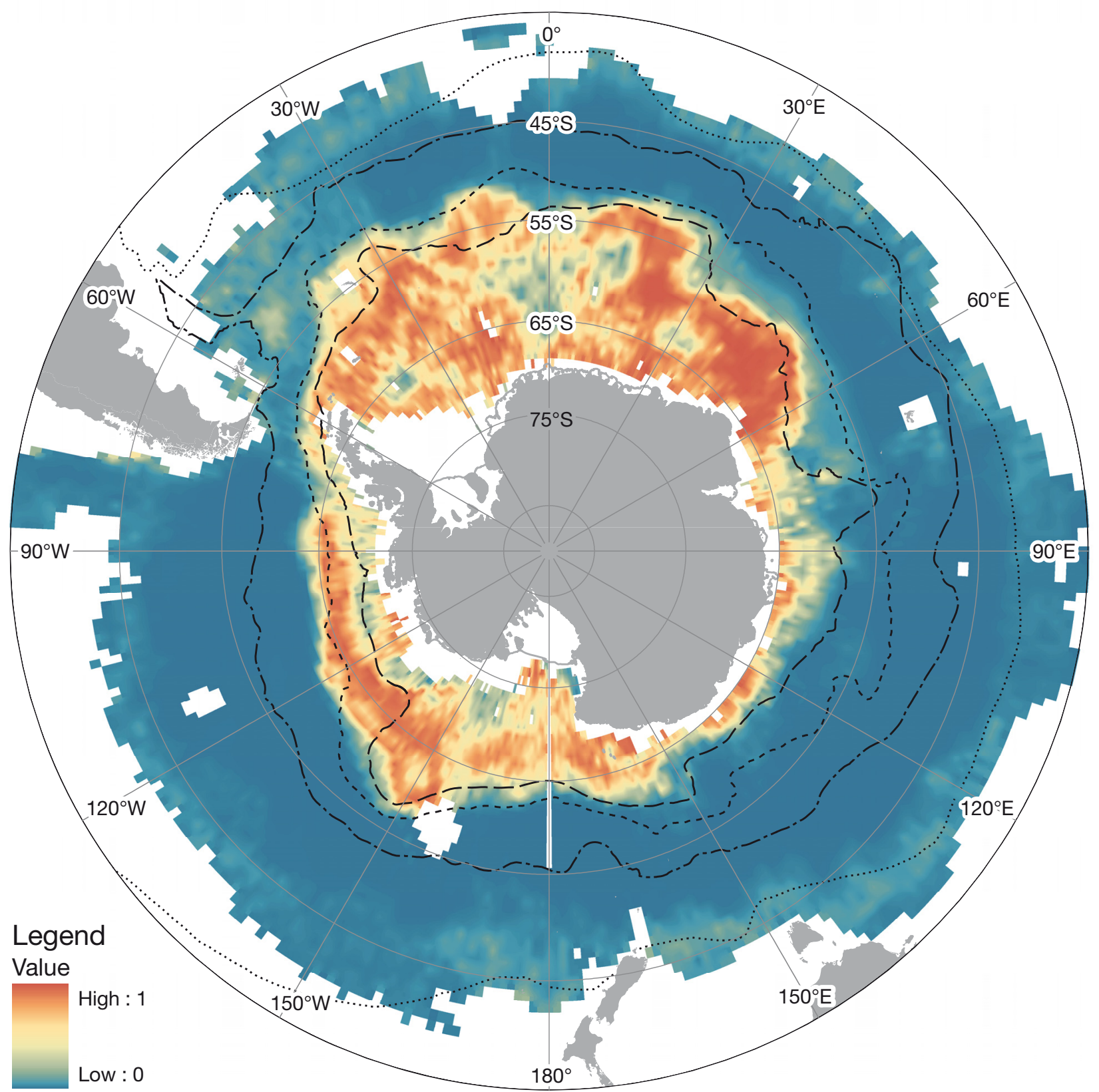

Fig. 5. Antarctic krill modeled habitat suitability using presence/absence data and environmental variables. (Source: figure and description used with permission from Cuzin-Roudy et al. 2014)

However, less attention has been paid to actual measurement of latitudinal shifts in the range of krill distribution. Using mixed models and a data timeseries derived from the KRILLBASE project (Atkinson et al. 2017), Atkinson et al. (2019) found that within the main population center, Antarctic krill distribution has shifted southward $(\sim 440 \mathrm{~km})$ over the past 90 yr (Fig. 6a). They linked this response to variation in the Southern Annular Mode (SAM); this index is strongly correlated with both sea-ice extent and water-mass distribution. High SAM values appear to be associated with low krill densities during the modern era (1976 to present) and across the southwest Atlantic sector (Atkinson et al. 2019). It is likely that the SAM influences annual recruitment of small $(<30 \mathrm{~mm})$ krill to the population through its influence on factors that determine high or low phytoplankton production: air and sea temperature (Clarke et al. 2007), duration and extent of sea-ice cover (Siegel \& Loeb 1995), cloud cover, wind condi- 


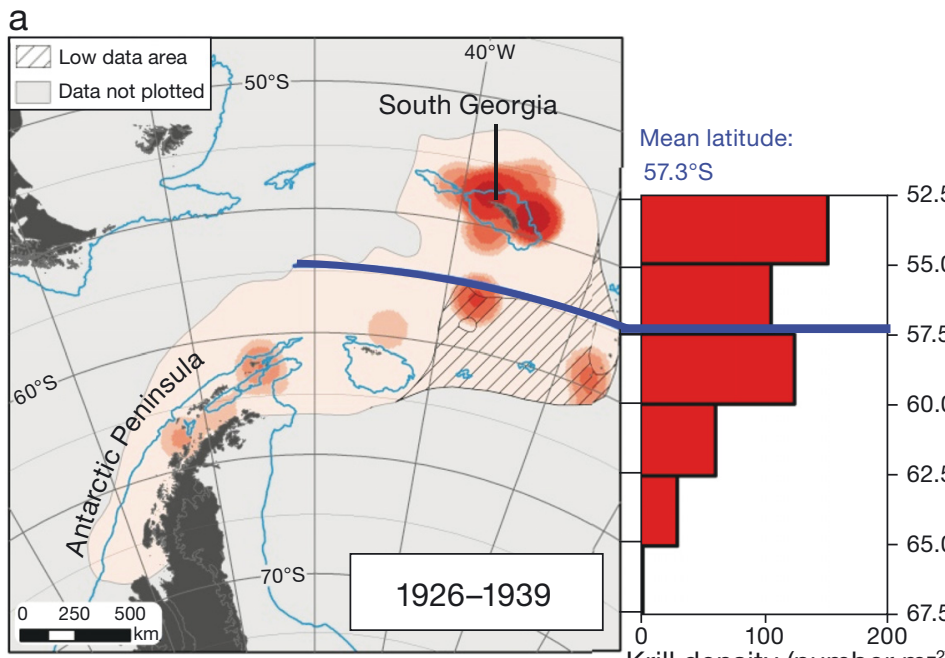

Krill density (number $\mathrm{m}^{-2}$ )

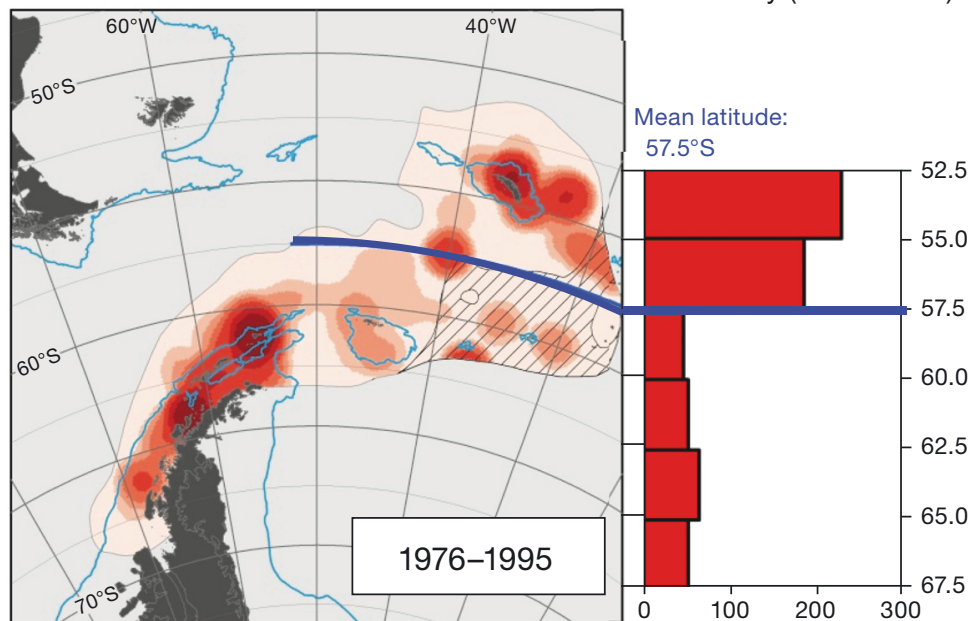

Krill density (number $\mathrm{m}^{-2}$ )



Fig. 6. Southward contraction of krill distribution within the SW Atlantic sector. (a) Kernel analysis visualizing hotspots of krill density in the SW Atlantic sector during the Discovery sampling era (1926-1939) and the first and second halves of the modern era, based on the area sampled heavily across all 3 periods. Blue isobaths denote the $1000 \mathrm{~m}$ boundary between shelf and oceanic habitats. Within each map, the kernel analysis identifies relative hotspot areas of high density, signified by the intensity of red shading. For a quantitative analysis, the histograms denote the mean density of krill in 6 comparable $2.5^{\circ}$ latitude bands with $>50$ stations sampled in each era. Note changes in scale. Thick blue lines across maps and histograms indicate the center of krill density (i.e. density-weighted mean latitude). (b) Trends in $\log _{10}$-transformed mean standardized krill density north and south of $60^{\circ} \mathrm{S}$. Small points represent the densities in underlying records; large dots represent the annual means of these data, weighted by the number of stations per record. Pink dots represent seasons with <50 stations (average 27 compared to an overall average of 123 stations per season). Solid blue trend lines were fitted using simple linear regression ( $p<$ $0.001, \mathrm{p}<0.01$ adjusted $\mathrm{R}^{2}=0.52,0.22$ for north and south of $60^{\circ} \mathrm{S}$, respectively). (Source: figure and description used with permission from Atkinson et al. 2019) 
tions (Wiedenmann et al. 2008), currents/circulation patterns, stratification, and advection (Flores et al. 2012a, Renner et al. 2012, Youngs et al. 2015).

The ongoing trend towards positive SAM - most notably around the Antarctic Peninsula and peripheral seas (Kwok \& Comiso 2002) - means warmer, windier, and cloudier weather, and loss of sea ice within the Southwest Atlantic sector, all of which negatively affect krill feeding conditions. This adversely affects early spawning in spring, early larvae in summer, and later larval stages which need early forming, complex, and well-illuminated marginal sea ice to promote survival (Meyer et al. 2017). Atkinson et al. (2019) reported that krill densities near the northern range limit have declined sharply: the population has become more concentrated in the south, where continental shelf habitat is more extensive. They noted that krill density shows a strongly negative trend north of $60^{\circ} \mathrm{S}$ and a weaker trend further south (Fig. 6b) and argued that SAM appears to be the clearest predictor at the whole Southwest Atlantic scale. The El Niño-Southern Oscillation (ENSO) is also identified as a driver of krill dynamics near the Antarctic Peninsula (Loeb et al. 2009). The interplay between SAM and ENSO strongly affects advection patterns and outflow from the northwestern Weddell Sea - influencing the advection of nutrients, phytoplankton, and krill towards either the western Antarctic Peninsula or towards South Georgia via the South Orkney Islands (Loeb et al. 2009, Renner et al. 2012, Youngs et al. 2015).

The findings of Atkinson et al. (2019) (Fig. 6) agree with predictions of poleward shifts in species distribution made by the Intergovernmental Panel on Climate Change (IPCC 2007). Uncertainties remain, however. For example, recent studies by Cox et al. $(2018,2019)$ - based on the same KRILLBASE dataset used by Atkinson et al. (2019) and Hill et al. (2019) — found no evidence of long-term decline in krill density or biomass, nor did they report a poleward contraction of distribution in the Southwest Atlantic sector. Contrasting results from these 2 studies regarding long-term changes in krill density and biomass may be due to fundamental differences in how these researchers pre-processed and transformed the data prior to submitting them to their respective modeling approaches, how log transformations were carried out, and statistical treatment of datasets. A fuller assessment of temperature effects might consider how the relationship between SST and the temperatures experienced by krill throughout the water column changes over time and space. The environmental effects are likely to be more com- plex than a simple poleward shift in distribution in response to increasing temperatures. Coastal embayments and high-latitude shelves may serve as refuges for growth but are unlikely to provide appropriate habitats for spawning (Hofmann \& Hüsrevoğlu 2003), or connectivity for subpopulations (Siegel 2005).

\subsubsection{Diminished krill habitat}

If a poleward shift in krill distribution has occurred, as argued by Atkinson et al. (2019), this is likely the coping response of a physiologically stressed organism to a rapidly changing environment. Such adjustments in species habitat may not meet the requirements for a population to persist, due to complex interactions among animal behavior, advection, and retention to maintain populations in specific regions (Hofmann \& Murphy 2004). Various aspects of the changed environment (e.g. temperature, availability and quality of food) will affect individual growth, reproductive success, survival rate, and recruitment success, as well as our ability to fully determine habitat requirements (Walther et al. 2002, Quetin et al. 2007).

One obvious aspect of a poleward shift in krill distribution is the inferred contraction into diminished habitat space-due to the meridians converging most rapidly at high latitudes - while further retreat is blocked by the continent itself (Atkinson et al. 2019). Such a shift may also involve declines in biomass and quality of phytoplankton food resources (Montes-Hugo et al. 2009), with negative impacts on feeding conditions, spawning success, and survival of larvae. The exact mechanisms are likely to vary with latitude (Meyer et al. 2017).

Quetin et al. (2007) noted 2 additional potentially important aspects of sustainable habitat relative to a poleward shift in krill distribution. Firstly, changes in latitude determine the seasonal cycle of light, and variation in the timing and amount of energy input into the ecosystem. The timing of ice formation at a specific latitude is crucial to the amount of food available to larval krill in their winter ice habitat. However, due to the differences in day length and sun angle, the amount of solar energy reaching the Earth's surfaces in autumn and winter is significantly less at higher latitudes. For organisms that can survive the autumn and winter with some light, but not total darkness, this decrease in light input may be critical. Secondly, the changing seasonal light cycle might directly impact krill physiology. This area of research on krill ecology has not received much attention. 
However, over the latitudinal range where krill are found, there may be differences related to seasonal shifts in the day/night light cycle: in behaviors such as the periodicity of diel vertical migration (Gaten et al. 2008); or in the timing of physiological processes such as the initiation of oocyte production (Spiridonov 1995).

\subsection{Impacts on vertical distribution}

Krill was long considered an epipelagic species, with the bulk of its biomass centered within the upper 150 m (Demer \& Hewitt 1995, Lascara et al. 1999), exhibiting diel vertical migrations of limited amplitude (Godlewska 1996), and seasonal variability in vertical distribution and abundance (Lascara et al. 1999). Early reports of krill occasionally descending to great depths were viewed as novel findings (Marr 1962, Lancraft et al. 1989, Daly \& Macaulay 1991) Routine krill surveys have generally focused only on the upper $200 \mathrm{~m}$ (Hewitt et al. 2004a,b, Siegel 2005); the general lack of documented evidence of downward migration can be explained by limited sampling capabilities at depth.

More recent studies indicate that krill-benthos interactions may be widespread, with the numbers observed at the seabed varying from a few individuals to dense swarms (Schmidt et al. 2011). Schmidt et al. (2011) showed that adult krill may occur in lowtemperature benthic habitats year-round in shelf and oceanic waters throughout their circumpolar distribution (Gutt \& Siegel 1994, Clarke \& Tyler 2008, Schmidt et al. 2011, Cleary et al. 2016). Additionally, net and acoustic data from the Scotia Sea showed that during summer, between 2 and $20 \%$ of the population can be found at depths between 200 and $2000 \mathrm{~m}$, and that large aggregations can form above the seabed.

\subsubsection{Benthic feeding}

It has long been reported that krill respond to changing conditions at the surface, with respect to food availability and the risk of predation, by migrating vertically in the water column (Russell 1927). Going deeper is likely to reduce food intake (De Robertis 2002, Burrows \& Tarling 2004) due to intraspecific interference and competition (Morris et al. 1983, Hamner \& Hamner 2000, Ritz 2000, Cresswell et al. 2009), However, benthic migrations may well be a critical life strategy that increases resource par- titioning within the population and contributes to the flexibility and overall success of the species (Schmidt et al. 2011).

Early acoustic measurements were largely restricted to depths ranging from 10 to $200 \mathrm{~m}$, and net collections were derived from tows over the upper $120 \mathrm{~m}$. Consequently, krill abundance in deeper waters cannot be estimated using these datasets. Lascara et al. (1999) suggested that the downward migration of krill, either as individuals or aggregations, to depths typically not sampled by nets and acoustics could explain estimates of reduced krill abundance during the fall and winter. The extent to which krill regularly inhabit depths below $200 \mathrm{~m}$ as an overwintering strategy remains a question for future research, but further details and observations of downward migration have been reported more recently.

The krill found at depth are usually adults (Schmidt et al. 2011) with strong swimming abilities (Kils 1981, Hamner et al. 1983, Huntley \& Zhou 2004) that enable them to migrate substantial distances within relatively short time periods. Although seabed feeding is thought to have lower energetic benefit, especially when combined with long-distance migrations, it is probable that body length and wet weight of adult krill confer a substantial potential for vertical migrations (Schmidt et al. 2011).

Studies of benthic-deposit feeders have shown that high-quality organic matter can be available on the seabed even in winter (Smith \& DeMaster 2008). The presence of benthic 'food banks,' where phytoplankton is accumulated, temporarily buried, and slowly degraded, make the seabed an attractive and attainable alternative feeding ground (Smith et al. 2006). Krill can use these food banks efficiently because they are adapted to feeding on surfaces (Hamner et al. 1983), and their high mobility gives them an advantage in locating patchy food sources (Schmidt et al. 2011). Cresswell et al. (2009) and Schmidt et al. (2011) also concluded that vertical feeding migrations by krill are flexible (facultative) and may be induced by suboptimal feeding in surface waters. Predicted future decreases in levels of chl a in important local/regional krill habitats would likely lead to increasing occurrence of seabed foraging (Smith et al. 2006).

\subsubsection{Vertical shift}

It is evident that deep migrations and foraging on the seabed are significant aspects of krill ecology. Kawaguchi et al. (1986) used a light trap to document 
krill feeding on detritus on the seabed during the dark period. Clarke \& Tyler (2008) further challenged the traditional view of krill being an epipelagic species with images taken from a remotely operated vehicle which showed krill feeding at the seabed at depths down to $3500 \mathrm{~m}$, and recent observations indicate that a substantial proportion of the population may be found below the upper $200 \mathrm{~m}$ epipelagic zone (Schmidt et al. 2011, Siegel \& Watkins 2016).

Fatty acid and microscopic analyses of stomach content confirm 2 different foraging habitats for krill: the upper ocean, where phytoplankton is the main food source; and deeper water or the seabed, where detritus and copepods are consumed (Schmidt et al. $2011,2014)$. Local differences in the vertical distribution indicate that reduced feeding success in surface waters can drive these vertical migrations, as can variations in predation pressure from air-breathing predators. Krill caught in upper waters retain signals of benthic feeding, suggesting a frequent and dynamic exchange between surface and seabed (Schmidt et al. 2011). Moreover, juvenile and larval krill may be important resources for chaetognaths and other invertebrates deeper in the water column (Trathan et al. 2003).

Seabed foraging behavior in krill may prove essential to the future success of this stenothermal species in a warming climate. Schmidt et al. (2011) considered factors potentially influencing the occurrence of krill swarms well below the population center to include food availability, predator avoidance, and transit to greater depths. Inherently, feeding success near the surface may be low due to food shortage or predator avoidance. Unfavorable surface conditions can occur close to land, where the impact from airbreathing predators is high, or far from land, where phytoplankton concentrations are relatively low even in summer. In both zones, the larger portions of the krill population in the deepest stratum of shipbased acoustic detection (200-300 m), compared to those found at intermediate distances from land, indicate that under such conditions some krill migrate away from surface waters to feed at depth. At intermediate distances from land, predation risk is usually reduced, and moderate to high phytoplankton abundances favor a shallow krill distribution (Schmidt et al. 2011).

Questions regarding the proportion of the circumpolar krill population engaging in deep migrations and benthic feeding have implications not only for ensuring reliable estimates of stock size, but also regarding the overarching effects of climate change on Southern Ocean ecosystems. The Antarctic sea- bed has traditionally been regarded as cold and thermally stable, with little spatial or seasonal variation in temperature. An analysis conducted by Clarke et al. (2009) highlighted aspects of the spatial and depth distribution of bottom temperatures which have not yet been integrated into discussions of the ecology or physiology of Antarctic benthic organisms, including krill. Noteworthy here is the striking difference between the thermal environment of the continental shelf seabed west of the Antarctic Peninsula and that of continental shelves around Antarctica. Clarke et al. (2009) found that deep-sea seabed temperatures are coldest in the Weddell Sea, becoming progressively warmer to the east. There is a distinct latitudinal gradient in the difference between seabed temperatures on the shelf and in the deep sea, with the deep sea being warmer by up to $\sim 2^{\circ} \mathrm{C}$ at high latitudes and colder by $\sim 2^{\circ} \mathrm{C}$ around sub-Antarctic islands. These differences may have important consequences for the benthic ecology and biogeographic assemblage composition of benthic fauna. Better understanding of past evolutionary history is needed, as well as of the potential impact of future regional climate change on krill production, with consideration of both vertical and horizontal shifts in its distribution (Clarke et al. 2009).

\subsubsection{Benthic-pelagic coupling and nutrient cycling}

The vertical fluxes involved in this seabed-feeding behavior are important for the coupling of benthic and pelagic food webs and cycling of the iron needed for phytoplankton production (Schmidt et al. 2011). The regular appearance of krill in the stomachs of demersal fish and brittle stars indicates their role as a food source for benthic predators. Thus, on their downward migration, krill contribute to the export of carbon and nutrients from surface water to the deep ocean - due to their excretion, defecation, and consumption by predators. Conversely, the occurrence of benthos-derived food in the stomachs of krill sampled in the upper $200 \mathrm{~m}$ water column indicates that, on returning from the depths, krill also reintroduce consumed benthic material back into surface waters. Even if some gut content is lost during transit, benthic feeding by krill and their subsequent return to surface waters may lead to a net upward flux of certain nutrients and trace metals (Schmidt et al. 2011).

Atkinson et al. (2009) estimated total circumpolar biomass of krill to be $379 \mathrm{Mt}$ (based on standardized trawl-net survey sampling data) and $117 \mathrm{Mt}$ (unstan- 
dardized data). These estimates are within the range of acoustics-based estimates of 60-420 Mt (Nicol et al. 2000b, Siegel 2005). It is also estimated that krill contain up to $260 \mathrm{nmol}$ iron per stomach when returning from seabed foraging; about $5 \%$ of this iron is labile and potentially available to phytoplankton (Schmidt et al. 2011). For this reason, it is important to know the proportion of the circumpolar krill population engaging in deep-sea migrations and benthic feeding in order to obtain reliable estimates of stock size and to anticipate the overarching effects of climate change on Southern Ocean ecosystems. Even if only a small part of this massive krill population migrates between surface and seabed, there will be consequences relating to the redistribution of organic matter and nutrients when feeding locations of migrants differ from the locations where excretion, defecation, or consumption occurs. This will have implications for benthic-pelagic coupling and nutrient cycling within Southern Ocean food webs (Schmidt et al. 2011). Survey-based assessments of biomass have failed to account for krill deeper in the water column. Regrettably, such critical background information on deep-sea migrations and benthic feeding by krill, i.e. causes, nutritional benefit, and percentage of the population involved, is still limited, and has not been incorporated into krill energy budgets (Fach et al. 2006), life-history models (Nicol 2006), or stock assessments (Siegel 2005, Schmidt et al. 2011).

\section{INTERACTION WITH OTHER ENVIRONMENTAL CHANGES}

As described above, the high mobility of krill, combined with its narrow range of temperature tolerance and its dependence on sea-ice habitat during critical life stages, imply that the warming underway in regions of the Southern Ocean may impact the migratory patterns and spatial distribution of this keystone species within Antarctic food webs.

Such shifts in krill distribution in response to climate change will act in concert with other environmental changes to impact krill distribution and abundance. These include ongoing ocean acidification (Flores et al. 2012a, Kawaguchi et al. 2013a,b), stillelevated levels of ultraviolet radiation (Newman et al. 1999, Flores et al. 2012a), and increasing abundance and distribution of salps (Atkinson et al. 2004).

Flores et al. (2012a) described the potentially cumulative negative impacts of ocean warming on krill populations, as summarized in Fig. 7. They suggested

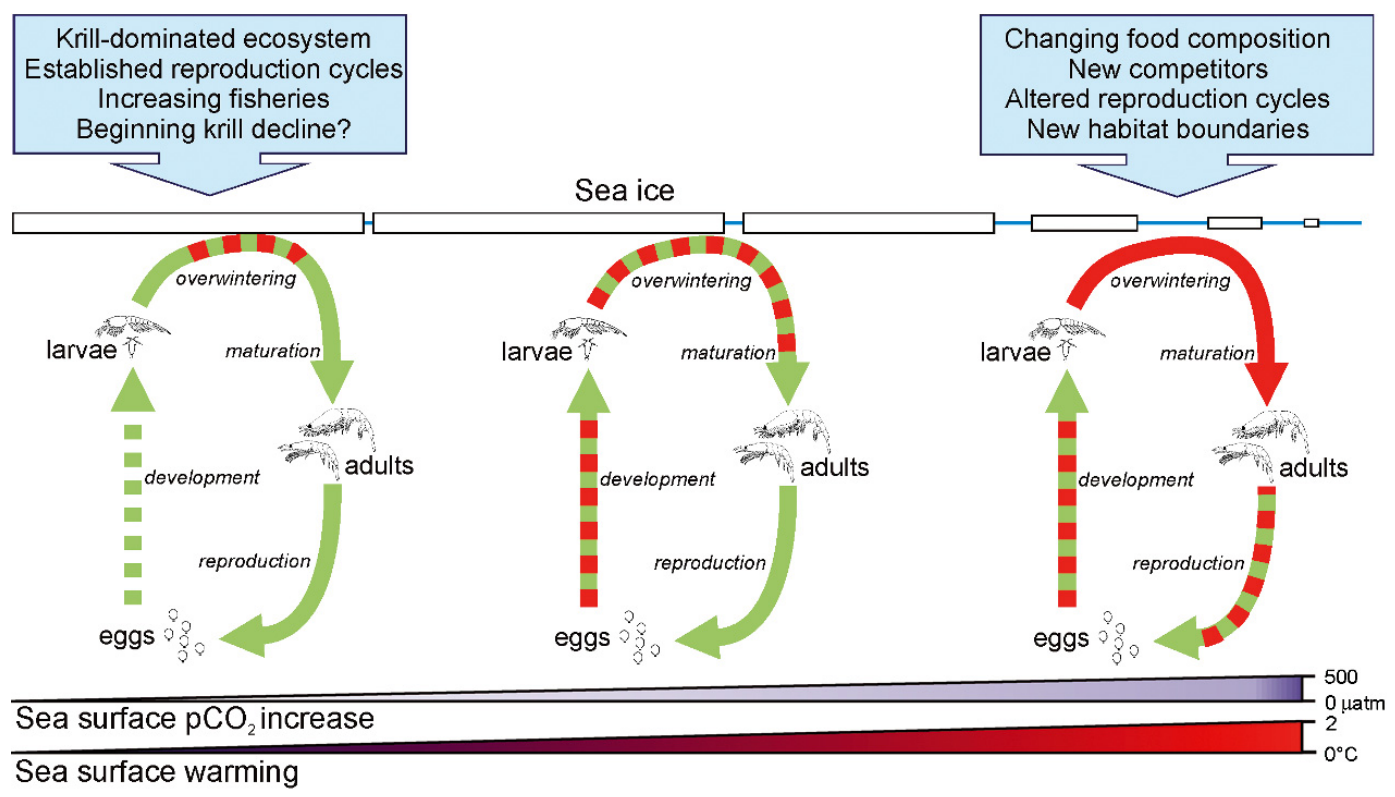

Fig. 7. Conceptual representation of cumulative impact of climate change on the Antarctic krill lifecycle in a typical habitat under projected scenarios for the $21^{\text {st }}$ century. Key processes are represented by green arrows. Processes under pressure of ocean warming, $\mathrm{CO}_{2}$ increase, and sea-ice decline are represented by red hatching; the solid red arrow indicates high risk of life-cycle interruption. The ecological position of krill may change from a present state (a keystone species with long-established reproduction cycles) to a future state, in which it faces different food sources and new competitors, demanding that it adapt its lifecycle to altered habitat conditions within new spatial boundaries. (Source: figure and description used with permission from Flores et al. 2012a) 
that until the ozone layer has fully recovered, UV radiation will be an additional environmental stressor on krill and Antarctic ecosystems; and that recruitment, driven largely by the winter sea-ice-dependent survival of larval krill, is the population parameter most susceptible to climate change. In this section, we explore these and other potential impacts on the krill resource, including new habitat boundaries via horizontal and vertical shifts in krill distribution; new competitors via the increasing distribution and abundance of salps; and increased predation pressure following a potential return of the great whales.

\subsection{Ocean acidification}

Loss of sea ice and high rates of primary production over the continental shelves, coupled with increased ocean-atmosphere gas exchange $\left(\mathrm{CO}_{2}\right)$, mean that the Southern Ocean will be among the first to become undersaturated with respect to aragonite (Fabry et al. 2008, 2009, McNeil \& Matear 2008, Feely et al. 2009, Orr et al. 2009, Weydmann et al. 2012, Kim \& Kim 2021). This will likely have biochemical and physiological effects on krill at different life phases, although the level of ocean acidification at which severe effects can be expected is unclear (Orr et al. 2005, Fabry et al. 2008, Flores et al. 2012a).

Krill eggs sink from the surface to hatch and develop at 700-1000 m. Present $p \mathrm{CO}_{2}$ values at this depth range ( $\left.550 \mu \mathrm{atm} p \mathrm{CO}_{2}\right)$ are already much higher than at the surface. Kawaguchi et al. (2013b) reported that under the RCP 8.5 scenario, krill in most habitats would suffer at least $20 \%$ lower hatching success by 2100 , with reductions of up to $60-70 \%$ in the Weddell Sea; and that the entire habitat may become unsuitable for hatching by the year 2300, leading to collapse of the krill population. There is clearly a need to improve our largely qualitative assessments of krill habitat (e.g. sea-ice impacts on recruitment) by integrating quantified relationships.

Model projections following RCP scenarios indicate that much of the current habitat for krill will have reached damagingly high $p \mathrm{CO}_{2}$ levels of $>1000 \mu \mathrm{atm}$ by the year 2100 under RCP 8.5, or by 2300 under RCP 6.0. These projections identify the Weddell and Haakon VII Seas off East Antarctica, and from the eastern Ross Sea to the western Antarctic, as areas with potentially high $p \mathrm{CO}_{2}$ values where krill egghatching is most likely to be at risk (Fig. 8) (Kawaguchi et al. 2013b).

Kawaguchi et al. (2011) demonstrated through experiments that krill embryos develop normally within a range of up to 1000 uatm $p \mathrm{CO}_{2}$. At $2000 \mu \mathrm{tm}$ $p \mathrm{CO}_{2}$, however, their development is almost completely inhibited and can be affected at concentrations as low as 1250 uatm (Kawaguchi et al. 2013a). Ericson et al. (2018) found that adult krill were able to survive, grow, store fat, mature, and maintain respiration rates when exposed to near-future ocean acidification conditions (1000-2000 $\mu$ atm $\left.p \mathrm{CO}_{2}\right)$, indicating that adult krill may have enhanced resilience.

Model-based projections of $\mathrm{CO}_{2}$ concentrations in seawater indicate that, by the year 2100, surface-water partial pressure of $\mathrm{CO}_{2}\left(p \mathrm{CO}_{2}\right)$ levels may reach 584 and $870 \mu \mathrm{atm}$ in the Scotia Sea and the Weddell Sea, respectively (Midorikawa et al. 2012). At greater depths, $p \mathrm{CO}_{2}$ levels may exceed 1000 uatm by 2100, even reaching nearly $\sim 1400 \mu \mathrm{atm}$ in the Weddell Sea region at depths of 300-500 m (Kawaguchi et al. 2011, Flores et al. 2012a). Variations in future seawater $p \mathrm{CO}_{2}$ levels around the Antarctic continent could be highly heterogeneous: seasonally, regionally, in surface waters, and at depth (McNeil \& Matear 2008). Some of the greatest increases are projected for areas where a large portion of the krill population occurs (S. Kawaguchi et al. unpublished data). Because $p \mathrm{CO}_{2}$ levels generally increase with depth, krill making extensive vertical migrations will spend much of their lives exposed to higher and more variable levels of ocean acidification than will organisms living primarily in surface waters (Kawaguchi et al. 2011).

Projections based on IPCC (2007) modeling scenarios indicate that Southern Ocean surface $p \mathrm{CO}_{2}$ levels may rise to $1400 \mathrm{pCO}_{2}$ within this century, but extreme levels approaching 2000 patm are unlikely. Inherent limitations of such predictions - relative to seasonal and regional variability, experimental approaches, availability of observational data at different depths, and incorporating the effects of climate change - limit the ability to estimate current and/or predict future $p \mathrm{CO}_{2}$ levels (McNeil \& Matear 2008). Moreover, quantitative assessment of the impact of ocean acidification on the growth potential of krill remains a key knowledge gap (Veytia et al. 2020), and whether Southern Ocean $p \mathrm{CO}_{2}$ will reach levels detrimental to krill remains an open question (Kawaguchi et al. 2010).

Because detrimental conditions may develop before the end of this century (Kawaguchi et al. 2013b), it is important to continue sustained observations of krill population and condition parameters at circumpolar scales throughout the lifecycle, to detect potential future effects of ocean acidification (Flores et al. 2012a). Current regular acoustic monitoring is limited to the most fishery-intensive areas. 



Fig. 8. Circumpolar risk maps of krill hatching success under projected future $p \mathrm{CO}_{2}$ levels. Hatching success under the RCP 8.5 emission scenario for (a) 2100 and (b) 2300; and under the RCP 6.0 emission scenario for (c) 2100 and (d) 2300 . Note the different color scales on each panel. Southernmost black line shows the northern branch of the Southern Antarctic Circumpolar Current Front; northernmost line shows the middle branch of the Polar Front. (Source: figure and description used with permission from Kawaguchi et al. 2013b)

\subsection{Increased ultraviolet radiation}

Despite the success of the Montreal Protocol in phasing out global emissions of ozone-depleting substances (ODS) (Farman et al. 1985), ozone depletion over the Antarctic has remained particularly high. Given the long lifetimes of many ODS in the atmosphere, this situation is expected to continue for several decades (WMO 2011, Williamson et al. 2014).

Ultraviolet B (UVB) radiation $(280-320 \mathrm{~nm})$ is the most harmful variant to reach the Earth's surface, and damaging irradiances have been observed to penetrate to biologically significant sea depths (HolmHansen et al. 1989, Gieskes \& Kraay 1990, Karentz \& Lutze 1990, Smith et al. 1992, Marchant 1994). Due to the key role of krill in the Southern Ocean ecosystem, it important to determine whether increased UVB due to ozone depletion is having detrimental effects on the population. Wild-caught krill have been observed to contain proportions of mycosporine-like amino acids (MAAs) (Karentz et al. 1991, Dunlap \& Yamamoto 1995). These MAAs are produced by algae in re- 
sponse to ultraviolet irradiation; subsequently, they are consumed en masse by krill (Newman et al. 2000).

Newman et al. (1999) presented results from laboratory studies indicating that krill are extremely susceptible to levels of UV irradiation penetrating to depths of up to $10 \mathrm{~m}$ in clear Antarctic waters. They found that the mortality of juvenile krill was accelerated at relatively low levels of UVB radiation, and that krill are intolerant to photosynthetically active radiation (PAR). PAR and ultraviolet A (UVA) treatments both reduced krill activity, and the addition of UVB wavelengths caused further reductions. Notably, a subsequent laboratory study indicated that krill may be able to avoid regions of high UVB radiation, thereby reducing exposure to and risk of UVBinduced damage (Newman et al. 2003).

In the coming decades, UV radiation is likely to be an additional environmental stressor on krill and Antarctic ecosystems (Flores et al. 2012a). The direct impact of UVB on the krill population may occur through genetic damage (Jarman et al. 1999, Dahms et al. 2011), physiological effects (Newman et al. 1999, 2000), or behavioral reactions (Newman et al. 2003). Indirect effects may arise through declines in primary productivity caused by increased UV radiation and changes in food-web structure.

\subsection{Growing competition from salps}

Salps (mainly Salpa thompsoni) tolerate warmer water than krill and occupy extensive lowerproductivity regions of the Southern Ocean (Foxton 1966, Le Févre et al. 1998, Nicol et al. 2000a, Pakhomov et al. 2002). The occurrence of salps is reported to be increasing in the southern part of their range approaching the Antarctic continent (Fig. 9) (Atkinson et al. 2004). These planktonic tunicates are important components of marine food webs and are major consumers of production at lower trophic levels. While salps feed efficiently on a wide range of plankton (Foxton 1956), they may not efficiently transfer that energy up to higher levels of the food web (Loeb et al. 1997). The consequences of their trophic dynamics and changes in their abundance and distribution are likely to have major effects on the pelagic food web and on pelagic-benthic coupling, through the sedimentation of particulate matter (Raskoff et al. 2005).

As obligate filter feeders, salps tend to prefer oceanic regions with lower food concentrations (Le Févre et al. 1998, Pakhomov et al. 2002). Thus, lower productivity across most of the ACC means that suitable habitat for salps is much larger than for krill

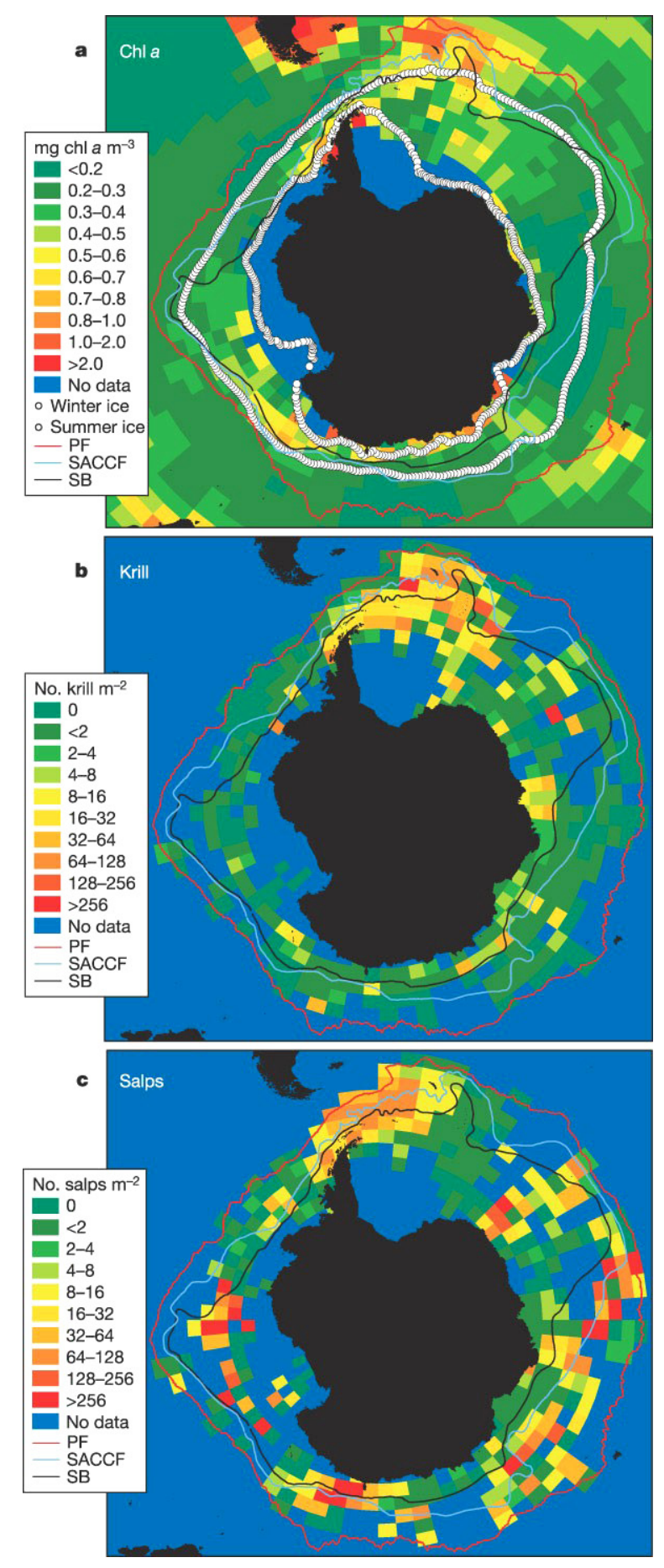

Fig. 9. Krill, salps, and their food. (a) Mean (NovemberApril) chl a concentration, 1997-2003. (b) Mean krill density (6675 stations, 1926-2003). (c) Mean salp density (5030 stations, 1926-2003). $\log _{10}\left(\right.$ no. krill m $\left.\mathrm{m}^{-2}\right)=1.2 \log _{10}(\mathrm{mg}$ chl $a$ $\left.\mathrm{m}^{-3}\right)+0.83\left(\mathrm{R}^{2}=0.051, \mathrm{p}=0.017, \mathrm{n}=110\right.$ grid cells $)$. Historical mean positions are shown for the $\mathrm{PF}^{29}$, Southern ACC Front $(\mathrm{SACCF})^{30}, \mathrm{SB}^{30}$ and northern $15 \%$ sea-ice concentrations in February and September (1979-2004 means). PF: Polar Front; SB: Southern Boundary. (Source: figure and description used with permission from Atkinson et al. 2004) 
(Atkinson et al. 2004), and studies have found some competition between these 2 species (Loeb et al. 1997). With shorter lifecycles than krill and explosive population growth rates, salps can respond to environmental variation over shorter timescales (Foxton 1966, Le Févre et al. 1998, Pakhomov et al. 2002). This, together with rising temperatures and reduced sea-ice coverage, heightens the potential for further increases in salp abundance.

The western Antarctic Peninsula - a key spawning and nursery area for krill — is warming quickly, and winter sea-ice duration is shortening (Parkinson 2002). Deep-ocean temperatures have increased (Gille 2002), and decreases in pre-1970s circumpolar sea-ice distribution have been found at several locations (Clarke \& Harris 2003, Curran et al. 2003). A study of temporal trends (inter-annual variability) in krill and salp density indicated that salp densities increased south of the Southern Boundary over the entire time-series (Atkinson et al. 2004). In contrast, densities for krill in the SW Atlantic sector have declined significantly since 1976. Although salps and krill usually occur in different water masses, salps occupy larger habitats than krill and are less affected by ongoing temperature changes. Further studies are needed to clarify the competitive elements in the relationship between these species. As the mechanisms underlying these changes are uncertain, any future predictions must be made with caution (Atkinson et al. 2004).

\subsection{Potential return of the great whales}

The removal of large whales from the Southern Ocean stands as one of the most dramatic and destructive exploitations of natural resources carried out by mankind. It is estimated that the abundance of large baleen whales decreased by $68 \%$ (range: 3$99.6 \%$ ) during the 1900s (Christensen 2006). For major krill predators combined (sei, fin, blue, and humpback whales), the estimated decrease was over $90 \%$. Rough estimates (using relationships presented by Reilly et al. 2004) indicate that the pre-exploitation krill consumption by these large baleen whales combined was $0.85 \mathrm{Mt} \mathrm{d}^{-1}$, or (assuming a $120 \mathrm{~d}$ residence

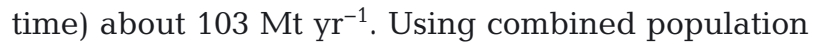
abundance estimates of predominantly krill-feeding whale species in 2001, the corresponding estimate of krill consumption by whales was $0.08 \mathrm{Mt} \mathrm{d}^{-1}$, or 10

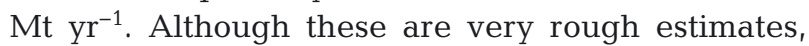
they indicate the potential impact of consumption by pre-exploitation whale populations on krill stocks.
The rate of whale stock recovery in the Southern Ocean has varied among species, but many stocks are now well on their way. In the case of humpback whales, the current population size in the Scotia Sea is estimated to be $\sim 91 \%$ of pre-exploitation levels, and the predicted size by 2030 is $\sim 98.8 \%$ of preexploitation levels. It is safe to assume that similar recoveries have occurred elsewhere in the Southern Ocean. Using the rough estimates presented above, continued recovery of this species alone could represent an increase in annual krill consumption of almost $1 \mathrm{Mt} \mathrm{yr}^{-1}$ from today through 2030. Assuming all baleen whales recover at similar rates, krill consumption by these large predators would be expected to increase dramatically over the coming decades. In contrast, a recent article by Tulloch et al. (2019) used a coupled climate and ecosystem model to predict future changes in krill and whale abundance in the Southern Ocean. Their model suggests that while many whale stocks may increase over the short term, predicting longer-term trends is more uncertain and problematic.

It should be noted that increasing population trends in other marine mammal species predating heavily on krill, notably Antarctic fur seals Arctocephalus gazella in South Georgia and other regions of the Southern Ocean, will also impact the krill population status (Hucke-Gaete et al. 2004).

\section{IMPLICATIONS FOR THE MANAGEMENT OF KRILL FISHERIES}

Ongoing environmental change will influence the lifecycle of krill and its spatial distribution. It is critical that the rate of climate-related changes not outpace the capacity to ensure sustainable management of the krill fisheries (Jacquet et al. 2010, Schiermeier 2010, Trathan \& Agnew 2010, Flores et al. 2012a, Constable et al. 2014).

This section briefly reviews the institutional framework for managing krill fisheries and its capacity to adapt to ongoing and future climate-related changes to the marine ecosystem. We focus on the rising attention paid to climate change within the decisionmaking and advisory bodies of CCAMLR; the need for regularly updated assessments of risks posed by fishing under a changing climate, based on monitoring of the ecosystem; and finally the advances made toward an adaptive management system capable of adjusting management actions in response to the best available information on the status of krill and its predators. 


\subsection{Institutions and fisheries}

The Convention on the Conservation of Antarctic Marine Living Resources (UNTS 1329-22301; United Nations 1980) was adopted amidst concerns that expanding fisheries could have substantial negative impacts on the Southern Ocean ecosystem. Its objective set forth in Article II is 'the conservation of Antarctic marine living resources' (p. 49), requiring that any harvesting operations 'shall be conducted in accordance with $[\ldots]$ the following principles of conservation: (1) Prevention of decrease in the size of the any harvested population to levels below those which ensure its stable recruitment $[\ldots]_{i}$ (2) Maintenance of the ecological relationships between harvested, dependent, and related populations [...] and the restoration of depleted populations [...] (p. 49); and (3) Prevention of changes or minimization of the risk of changes in the marine ecosystem which are not potentially reversible after two or three decades [...]' (p. 50).

Present-day krill catch levels ( $\approx 450000 \mathrm{t}$ in 2019/ 20) have not reached the current catch limit for the Southwest Atlantic sector $\left(620000 \mathrm{t} \mathrm{yr}^{-1}\right)$ and are taken largely by Norway, South Korea, and China in an 'Olympic-style' (no national or vessel quota) fishery; Ukraine, Chile, and in some years Russia and Japan also participate (CCAMLR 2018). Established fisheries exist in East Antarctica (Food and Agriculture Organization Subareas 58.4 subdivisions 1 and 2) and the southwest Atlantic (Subareas 48.1-4), although since the early 1990s, harvesting has been concentrated in the Scotia Sea and western Antarctic Peninsula (Fig. 10).

In the management of this fishery, CCAMLR's ecosystem objective implies an obligation to also consider impacts on krill-dependent species, including penguins and other sea birds, fish, seals, and whales (Hill et al. 2016, Watkins et al. 2016). The institutional framework for pursuing this objective comprises the decision-making Commission and the advisory Scientific Committee (SC-CAMLR), both with subsidiary bodies, plus a Secretariat.

The Commission meets annually and adopts, by consensus, legally binding Conservation Measures. For krill, the Commission has set maximum removals from each statistical subarea where the fishery occurs, placed stringent restrictions and data-collection requirements on exploratory fisheries in new areas, and obliged Members to notify the Secretariat of vessels planning to participate in the krill fishery. Members must also report regularly on catch and effort and ensure that their vessels adhere to all krill-specific or general regulations on matters such as vessel marking, gear restrictions, and bycatch mitigation.

The Scientific Committee is charged with promoting cooperation on research with respect to Antarctic marine living resources and to advise the Commission on measures for implementing the objectives of the Convention (Article XV). This advice derives from assessments conducted by 5 working groups: Ecosystem Management and Monitoring (EMM), responsible for krill, including predator-prey interactions and how they relate to environmental features; Acoustic Survey and Analysis Methods (ASAM); Statistics, Assessments and Modelling (SAM); Incidental Mortality Associated with Fishing (IMAF); and Fish Stock Assessment (FSA), responsible for targeted finfish resources, mostly toothfish. Sources of data include scientific surveys, the CCAMLR Ecosystem Monitoring Programme (CEMP), commercial catch reports, and a Scheme of International Scientific Observers (SISO).

The Convention's spatial ambit (southward of the Antarctic Polar Front, Article I) and placement in a

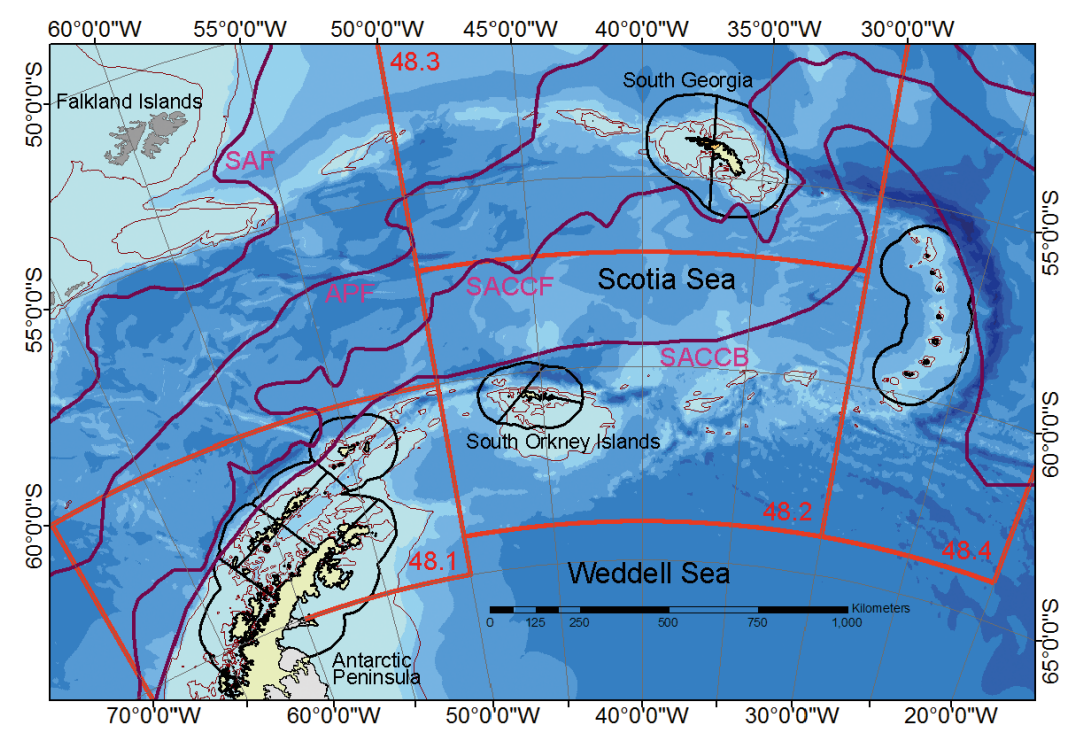

Fig. 10. Antarctic Peninsula, Scotia Sea, and Weddell Sea. Boundaries of FAO Statistical Subareas 48.1-4 are shown in red, as are boundaries of the CCAMLR Small Scale Management Units (SSMUs, not yet used for management purposes) for the krill fishery in black. Major fronts of the Antarctic Circumpolar Current (ACC) shown in pink: Southern ACC Boundary (SACCB); Southern ACC Front (SACCF); Antarctic Polar Front (APF); and Sub-Antarctic Front (SAF). (Source: BAS 2018). Courtesy of Dr. Philip Trathan, Head of Conservation Biology, British Antarctic Survey 
larger institutional complex (the Antarctic Treaty System [ATS], including the Convention on the Conservation of Antarctic Seals; see Stokke \& Vidas 1996) are conducive for ecosystem-based management. Among the major krill predators, only whales are managed by an institution outside the ATS: the International Whaling Commission. CCAMLR also cooperates with that institution as it does with the Commission for the Conservation of Southern Bluefin Tuna, which manages a stock with some occurrence in northern parts of the CCAMLR Area. However, since the last meeting between CCAMLR and the IWC in 2008 (SC-CAMLR 2008, Annex 12), there has been very little consideration given to the recovery and distribution of cetacean krill predators in terms of krill fisheries management.

\subsection{Climate change and CCAMLR}

A recent review of responses to climate change by regional fisheries management bodies found that CCAMLR has been more explicit than other organizations on the need to take climate change into consideration, adding, however, that none of them had advanced substantially toward integrating climate impacts into their research and regulatory activities (Rayfuse 2019). References to climate change and its potential impacts on the Southern Ocean ecosystem are traceable in Scientific Committee reports since 1989 (SC-CAMLR 1989, Annex 2) but their frequency and prominence were low well into the 2000s. Like for other fisheries management bodies (Sumby et al. 2021), a turning point occurred in 2007, which coincides with the publication of the IPCC Fourth Assessment Report as well as the International Polar Year (2007-2008) with its many climate-related projects. That year, the Commission 'urged Members to develop and maintain long-term scientific monitoring programs studying the krill-based ecosystem as these will allow the Scientific Committee to investigate the effects of climate change as well as the effects of the fishery' (CCAMLR 2007, p. 14). The Commission also noted that climate-change impacts could be upgraded to a separate agenda item for the Scientific Committee (CCAMLR 2007), thereby reinforcing expectations of concrete advice on the matter. The year after, it endorsed 3 work areas designated by the Scientific Committee with a view to examining (1) the robustness of stock assessments and scientific advice to the rising uncertainty accompanying climate change; (2) the need for improved monitoring programs of harvested and associated species to pro- vide robust and timely indicators of climate change impacts; and (3) whether climate-change uncertainty implies modification of management objectives or performance indicators (CCAMLR 2008).

Subsequent progress in these 3 work areas has been uneven. Within the first 2, on robustness and monitoring, the Scientific Committee soon advised that climate change has the potential to induce rapid change within ecosystems and that distinguishing climate impacts from fisheries impacts would likely require that existing CEMP sites for ecosystem monitoring be supported by data collection in reference areas with no fishing (SC-CAMLR 2009). The Commission responded promptly: it adopted Resolution 30/XXVIII, urging Members and others to increase their consideration of the impacts of climate change in the Southern Ocean to better inform CCAMLR management decisions, and endorsed a review of CEMP (CCAMLR 2009a). More than a decade later, however, that CEMP review is still forthcoming, awaiting consensus within the Commission on a new krill management procedure (SC-CAMLR 2018) which in practice requires successful completion of the third designated work area, on possible modification of management objectives and performance indicators (see Section 5.4).

Since 2015, the Commission has examined climatechange impacts on conservation as a separate agenda item, involving controversy over 2 issues in particular: a proposed addition to Resolution 30/XXVIII, requesting that all papers submitted to the Scientific Committee or the Commission should include a climate-change implications statement; and a proposed Climate Change Response Work Program (CCRWP) modeled on one implemented by the Committee for Environmental Protection Antarctic Treaty's Environmental Protocol (CCAMLR 2017). The controversy over climate-change statements has revolved around the scientific value of requiring such statements also in CCAMLR papers that do not examine time-series of climate data (e.g. CCAMLR 2018b). Critics of the CCRWP have focused on its proposed mechanism for identifying and revising climate-change responsive goals and actions by the Commission and the Scientific Committee, arguing that it might duplicate activities in other forums and bypass assessment by the Scientific Committee and its working groups (e.g. CCAMLR 2018b).

Although climate change has been subject to rising attention in CCAMLR, the agreed approach has been to deal with its implications not by climatespecific requirements or structures, but by seeking to improve the general institutional capacity to detect 
and respond to any detrimental impacts of harvesting. With respect to the krill fisheries, as the remainder of this section shows, those efforts have revolved around risk assessment procedures and the Commission's long-standing aspiration to move closer to a feedback management system.

\subsection{Toward ecosystem risk assessment}

The harvesting pressure on Antarctic krill in the Southwest Atlantic sector, where the fishery is concentrated, has never exceeded $1 \%$ of the estimated spawning-stock biomass in this area. Assessments of risk have therefore focused less on replenishment of the krill stock than on any impacts that reduced abundance may have on krill-dependent predators in the local areas where fisheries occur.

Catch reports from the commercial krill fisheries, required by CCAMLR on a haul-by-haul basis at gradually finer spatiotemporal scales, are the main sources of data on the distribution of harvesting operations. Several factors, including the patchiness of these operations compared to the distribution of the stock and the scarce knowledge held on the mechanisms and patterns of krill flux (movement), limits the use of catches per unit effort for stock-assessment purposes (SC-CAMLR 1989, Santa Cruz et al. 2018), so abundance estimates derive mostly from standardized net and acoustic surveys (Meyer et al. 2020). For cost reasons, large, area-scale surveys have been rare events - for the Southwest Atlantic sector, they were only conducted in 2000 and 2019. Regional biomass estimates, in contrast, as part of local monitoring programs in the main fishing areas have been sufficiently regular to provide time-series data revealing very wide fluctuations in local abundance such as in the Bransfield Strait and north of the South Shetland Islands where interannual differences can be as large as 2-3 orders of magnitude (Reiss 2008). Knowledge of such fluctuating abundance in fisheries hotspots has made the question underlying most of the krill management discussions in CCAMLR even more pressing: To what extent do krill fisheries put local predators at risk?

A major response to that question was the establishment in 1985 of CEMP, focused on selected lifehistory stages of land-based seals, penguins, and several other sea bird species with restricted mobility during the foraging season (Agnew 1997, Kock et al. 2007). A review of that program nearly 2 decades later, however, found it 'unlikely that the existing design of CEMP, with the data available to it, would be sufficient to distinguish between ecosystem changes due to harvesting of commercial species and changes due to environmental variability, whether physical or biological' (SC-CAMLR 2003, p. 8).

Ecosystem-based risk assessment of the krill fisheries therefore requires data on fisheries, on krill abundance at various scales (to account for flux), and on local predator requirements in fisheries hotspots (Krafft et. al 2015) - all collected and analyzed in ways that allow evaluation of functional relationships (Kawaguchi \& Nicol 2020, Meyer et al. 2020). When examining advances in the ecosystem risk assessment underlying Scientific Committee advice on krill, it is instructive to focus on a few particularly important decisions by the Commission:

(1) The advice to set a first precautionary catch limit on krill in the Southwest Atlantic sector (CM 30/X-1991; CCAMLR 1991b) was motivated by concerns that localized overfishing might negatively affect predator populations, fueled by fine-scaled fisher reports indicating concentration near colonies of foraging penguins and seals (SC-CAMLR 1991). The basis for setting this catch limit was data on krill abundance derived from surveys conducted in the pre-CCAMLR era; the first and second international BIOMASS experiments (BIOMASS 1986).

(2) A second important krill Conservation Measure (CM 46/XI-1992; CCAMLR 1992) subdivided the catch limit among subareas of the Southwest Atlantic, largely proportionally to distribution estimates from the pre-CCAMLR Area survey (SC-CAMLR 1992). Implementing that subdivision, however, would only be required if total catch in heavily fished subareas reached a 'trigger level' of $620000 \mathrm{t}$, corresponding to the highest recorded annual catch in each subarea. Whereas predator demand formed the basic rationale for the catch limit as well as the trigger, the report from the scientific deliberations made only a single reference to CEMP predator monitoring, by then underway for $7 \mathrm{yr}$ - namely that despite such monitoring 'it is currently impossible to estimate total consumption for all krill predators in the subareas' (SC-CAMLR 1992, p. 15).

(3) The next major step in krill conservation (CM 32/XIX-2000; CCAMLR 2000b) was taken immediately after the CCAMLR 2000 synoptic krill survey of the Southwest Atlantic sector: based on improved acoustic analysis methods, greater knowledge on krill life history, and a concomitant improvement in stock assessment methods, the Commission raised the precautionary catch limit for the area and spatially allocated it at the subarea level based on survey estimates of the stock distribution. Importantly, 
the Commission also upgraded the trigger level from a threshold obliging further subdivision to an arealevel interim catch limit, applicable until a subdivision of the much higher precautionary catch limit (currently at 5.61 Mt) is agreed (CCAMLR 2000a).

(4) To facilitate more resolved risk assessment and Conservation Measures, the Scientific Committee 2 yr later proposed a number of small-scale management units (SSMUs) - distinguishing in each subarea between 1 pelagic area and 1 or more land-based predator areas (SC-CAMLR 2002). However, disagreement on the feasibility and scientific merit of various options for subdividing the krill catch limit among them has so far prevented consensual advice on the matter. Static or dynamic options under longstanding evaluation by the Scientific Committee require finescaled distribution estimates of, respectively, (i) historical catches; (ii) krill biomass, as used already at the subarea level; (iii) predator demand; (iv) krill biomass minus predator demand; (v) dynamic predatorbased indices of krill availability; or (vi) ecosystem responses to structured fishing, in which harvesting effort rotates among SSMUs (e.g. SC-CAMLR 2004; see also Hewitt 2004b).

(5) The most recent substantive update of Conservation Measures related to krill fishing (CM 51-072009; CCAMLR 2009b) allocated the trigger level among 4 subareas (48.1-4) in the Southwest Atlantic, again largely based on survey-derived estimates of the standing krill stock (CCAMLR 2009a). Driving the subdivision was advice by the Scientific Committee, based on improved modeling of functional relationships among fisheries, krill, and spatially restricted predators which indicated that even the relatively low trigger-based catch limit might not suffice to protect predators should the fishery become more concentrated near foraging areas (SC-CAMLR 2009, Meyer et al. 2020). The Conservation Measure subdividing the trigger level was time limited and has been renewed several times: that currently in force expires in November 2021 (CM 51-07-2016; CCAMLR 2016b).

This brief review of the major decisions on krill thus far brings out the progress and limitations in CCAMLR's risk assessment. The 2009 decision to subdivide the trigger level drew upon multispecies modeling parameterized in accordance with the best available knowledge at that time on processes linking fisheries and ecosystem response, using spatially resolved data on variations in krill and predator abundance (Watters et al. 2013). The limitations are equally evident, however: neither the catch limit (based on historical fishing maxima) nor its subdivi- sion (based on estimates of krill distribution from the 2000 survey) reflect updated information from ongoing krill surveys and monitoring of predator abundance and reproductive performance. Important advances in understanding the krill-centric ecosystem had driven the decision to subdivide the triggerbased catch limit but not the substance of that decision.

A dynamic, whole-ecosystem, data-driven procedure that can support adaptive management of krill is still a work in progress (Kawaguchi \& Nicol 2020, Meyer et al. 2020), yet 3 moves by the Scientific Committee since the latest regulatory update deserve attention. In 2013, it consolidated a staged approach envisaging catch limits above the trigger level advised based on information that incorporates a steadily broader range of observation series, including multiple-scaled krill surveys and CEMPbased quantification of predator demand (SCCAMLR 2013). A second move was to develop a Risk Assessment Framework for providing advice on how to spatially distribute future catch levels to spread and moderate risks to predators (SC-CAMLR 2016). A third move was agreed immediately after the 2019 Area 48 Survey had demonstrated that commercial fishing vessels could effectively collect large-scale scientific data on krill (SC-CAMLR 2019a). The Scientific Committee adopted a detailed work plan to collate data layers and analyses from a wide range of past, ongoing, and enhanced monitoring and research activities - including the 2 large-scale area surveys, annual regional krill surveys and predator monitoring, and tracking of land-based and pelagic predators (SC-CAMLR 2019b).

\subsection{Politics of feedback management}

When adopting the first precautionary catch limit on krill in 1991, the Commission noted that although a precautionary approach was better than a reactive one, some form of 'feedback management, which involves the continuous adjustment of management measures in response to information, is to be preferred as a long-term strategy' (CCAMLR 1991a, p. 15). The Scientific Committee quickly pointed out that the information requiring response concerned 'interactions among krill, krill predators, the fishery and the environment' (SC-CAMLR 1992, p. 21).

For many years, as shown above, progress toward an approach that can support such feedback management was constrained by technology, analytical methods and monitoring design issues and by insufficient frequency and regularity of surveys and monitoring of 
krill and krill-dependent species. Scientific uncertainty concerning the impacts of krill harvesting on local ecosystems has contributed to longstanding disagreement among CCAMLR Members on when to subdivide catch limits among smaller management units in the Southwest Atlantic (e.g. CCAMLR 2016a). Finer subdivision is controversial because small management units imply less flexibility for fishing vessels to deploy their harvesting capacities efficiently. Even with the current much larger management units (4 subareas in the Southwest Atlantic sector), subdivision of the trigger-based catch limit regularly results in closures in parts of the operational area well before the season ends. Importantly though, static management measures requiring consensus to modify are unlikely to keep pace with the dynamic changes to the marine ecosystem and may thus hamper rather than promote the ability to react adaptively.

The balance between environmental protection and rational use of natural resources has been a central issue in CCAMLR from the outset (e.g. Press et al. 2019), most visibly in recent controversies over proposed marine protected areas (MPAs) (e.g. SykoraBodie \& Morrison 2019, Brooks et al. 2020). Both concerns are enshrined in CCAMLR's objective since, according to Article II, '[f]or the purposes of this Convention, the term 'conservation' includes rational use' (UNTS 1329-22301; United Nations 1980, p. 49). In the Scientific Committee's staged approach toward feedback management, the balance between protection and rational use is seen in the link between prospects for higher catch limits and adoption of decision rules to adjust Conservation Measures based on more reliable krill and predator data (SC-CAMLR 2013). Advances in ecosystem risk assessment, notably the development of a theoretical model for the risk assessment framework, the 2019 Area 48 synoptic survey, and agreement on a detailed work plan to collate multiple data streams, have clearly improved the prospects for moving that process further.

Moving from this first to the second stage in the process toward feedback management calls for skillful balancing of protection and rational use, since legally binding decisions by CCAMLR require consensus (Article XII). In fact, consensus is necessary even for remaining in the first stage, since the present subdivision of the trigger level expires in November 2021 (CM 51-07-2016; CCAMLR 2016b). From a governance standpoint, a consensus rule has the obvious disadvantage that decisions are easily blocked. The accompanying advantage, however, is that Members are compelled to search for solutions that accommodate strongly held concerns of others.
In CCAMLR, the consensus-seeking approach typically begins informally at the scientific workinggroup level so that, by the time an issue reaches the Commission, any disagreement has been aired and noted prior to the formal deliberations (Everson 2017). While this procedure holds no guarantee of consensus, it allows those who put forward a proposed Conservation Measure to adjust it in ways more acceptable to all. According to the Rules of Procedure of the Scientific Committee, its reports to the Commission 'shall reflect all the views expressed at the Committee on the matters discussed' (Rule 3, SC-CAMLR 1983, p. 51); this ensures a high degree of transparency regarding positions taken and arguments made by Members on controversial matters.

The active engagement of leading krill-fishing states to develop the scientific work plan supporting a feedback management strategy for the krill fisheries (SC-CAMLR 2019a) is conducive to obtain consensus because these states cannot be suspected of seeking to dilute the rational-use part of CCAMLR's conservation objective. A related and similarly conducive circumstance is the positive attitude expressed by important segments of the krill-fishing industry. Members of the Association of Responsible Krill Harvesting Companies (ARK) take more than $80 \%$ of the krill catch in the CCAMLR Area; their support advancing feedback management includes active engagement in scientific workshops and stakeholder meetings on the matter and providing vessel hours free of charge for the 2019 Area 48 Survey (SCCAMLR 2018). This association, which holds observer status within CCAMLR, also self-regulates harvesting activities by enacting voluntary restriction zones seasonally near breeding colonies of krill predators (CCAMLR 2016a). Among the drivers for these supportive activities is that major krill-fishing companies have obtained certification from a leading private governance institution, the Marine Stewardship Council (MSC), which now certifies more than $10 \%$ of the world's capture fisheries. MSC certification improves access to major markets for some of the most lucrative krill applications, such as nutrients and pharmaceuticals. Measures required or recommended by the MSC to renew existing certificates align well with the feedback management agenda: reduction of bycatch and localized harvesting pressure, and better knowledge of the effects of the krill fisheries on the ecosystem (e.g. Hønneland et al. 2020, Roel \& Ríos 2020; see also Nicol et al. 2012).

Another circumstance favoring progress toward feedback management is the substantial increase in krill catches over the past 5 yr. This rise derives from 
gradually stronger markets for an expanding range of krill-based products and possibly also from more efficient gear; notably, deployment of continuous pumping technology in part of the fishing fleet. The recent rise in catches is steeper than expected: industry sources cited by Kawaguchi \& Nicol (2020) found it unlikely that catches would exceed $350000 \mathrm{t}$ in the Southwest Atlantic, yet a catch close to $450000 \mathrm{t}$ was already reported in the 2019/2020 season (CCAMLR 2020). This development makes it more probable that commercially viable krill-harvesting could exceed the trigger level for the Southwest Atlantic sector. Lifting that trigger level will require consensus within the Commission on a mechanism to spatially allocate the higher Precautionary Catch Limit among smaller management units (CM 51-01-2010; CCAMLR 2010) — or on some other adaptive solution acceptable to all Members.

In summary, a combination of institutional, political, and economic considerations yields some optimism regarding the ongoing effort to move closer to a feedback management system for krill. Members emphasizing the protection part of CCAMLR's conservation objective have strong incentives to accommodate those leaning toward rational use - because without a new consensus decision, even the existing level of spatial distribution of fisheries will expire. Conversely, fishing states envisaging a continued rise in capacity and demand know that the catch limit will stay at $620000 \mathrm{t}$ unless all Members agree otherwise. Whatever the exact location of one's preferred balance between protection and rational use, status quo is becoming steadily less attractive as a long-term option.

\section{CONCLUSIONS}

Our review findings indicate that during the present century, Antarctic and Southern Ocean marine ecosystems are being subjected to climate-driven increases in ocean temperatures and changes in the extent and seasonality of sea ice. This rapidly warming climate, in concert with other environmental changes, i.e. increased UV radiation and ocean acidification $\left(p \mathrm{CO}_{2}\right)$, and changes in food-web structure, is altering the habitat, distribution, and abundance of krill.

Some reports indicate that changes in the horizontal distribution of krill have already occurred, notably a poleward contraction implying a reduction in available habitat for spawning and growth, but uncertainties remain. The limited observations of changes in vertical distribution indicate that a substantial pro- portion of the krill population occurs at depths lower than those measured by current survey sampling techniques, and that large aggregations can form above the seabed. Projected future changes include a sustained increase in ocean temperature and changes in sea ice and chl $a$. The effect of reduced sea ice and chl a concentrations is likely to be more significant than the direct effects of temperature increase and will cause some degradation of krill environments. This has caused, and will likely continue to cause, shifts in the spatial range (horizontal and vertical) of Antarctic krill stocks, by exacerbating the physiological challenges and reducing food availability.

The cumulative effects of these environmental changes will imply a significant, but as yet unknown, reduction in habitat suitable for krill spawning, hatching, larval survival, and juvenile growth. Uncertainties as to the extent of krill deep-sea migrations and benthic feeding have implications for reliable assessment of krill-stock biomass. It is important to know the proportion of the circumpolar krill population engaging in deep-sea migrations and benthic feeding to obtain reliable estimates of stock size and to anticipate the overarching effects of climate change on Southern Ocean ecosystems. A flow chart with the main findings from our review, connecting these environmental changes to the management of krill fisheries, is presented in Fig. 11.

Changing environmental conditions and prospects for future increases in the krill catch makes it even more pressing to overcome the long-standing impasse among CCAMLR Members on the development of an adaptive management system for the krill fisheries; one in which regularly updated information on krill and krill-dependent species forms the basis for risk assessment and, if necessary, adjustment of Conservation Measures. Progress towards such a system has been constrained by inadequate monitoring activities and lack of consensus on how to allocate catch levels spatially in order to spread and moderate risks to predators.

Recent developments reviewed here seem promising in both regards. In 2016, the Scientific Committee endorsed a conceptual model for the risk assessment framework. Three years later, the large-scale Area 48 Krill Survey enabled an updated stock assessment for the Southwest Atlantic sector where krill fishing is concentrated; and also in 2019, the Scientific Committee specified a comprehensive work plan to enable advice on spatial distribution of future catch limits based on a range of past, present, and planned monitoring activities. 


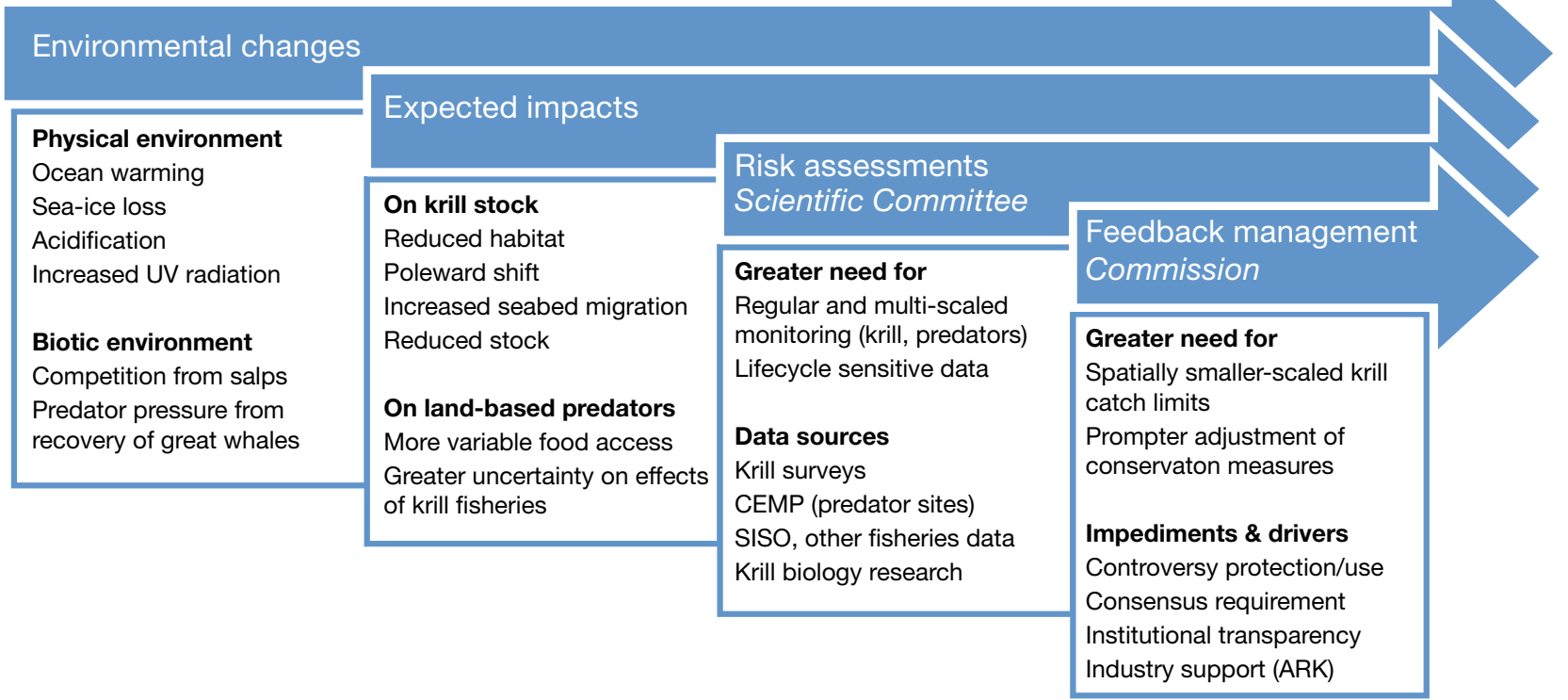

Fig. 11. Main findings from our review, including climate-driven environmental changes, expected impacts on krill distribution and abundance, and resulting challenges to and needs for more responsive ecosystem-based management of krill fisheries. CEMP: CCAMLR Ecosystem Monitoring Programme; SISO: CCAMLR Scheme of International Scientific Observation;

ARK: Association of Responsible Krill Harvesting Companies

Adoption of krill regulations with finer spatial resolution than found in current Conservation Measures requires consensus among CCAMLR Memberswhich in turn calls for mutual accommodation among parties to a decade-long debate over how to balance the protection and the rational-use parts of CCAMLR's conservation objective. We have noted several grounds for optimism regarding the prospects for such accommodation and for further progress toward adaptive krill management. First, the upcoming expiry of the Conservation Measure that distributes the trigger level among subareas in the Southwest Atlantic sector renders status quo less attractive to all parties to the protection-rational use debate. Members concerned that greater concentration of the fishery would undermine the protection of local predator stocks now have firm incentives to seek solutions that are palatable also to those emphasizing rational use. Conversely, Members concerned that the interim catch limit of $620000 \mathrm{t}$ will soon be a real constraint on harvesting operations have more compelling reasons than before to develop or endorse a procedure for spatial distribution because without it, they cannot hope to lift that limit. Secondly, leading fishing states and the companies responsible for most of the krill catch have actively promoted the advances recently made in monitoring and risk assessment procedures, helping to reduce concerns among some Members that a revised and adaptive krill management procedure might undermine the rational-use objective of CCAMLR.
Acknowledgements. Major funding for this work was from the Research Council of Norway through POLARPROG Project No. 257614: Spatial Shifts of Marine Stocks and the Resilience of Polar Resource Management (STOCKSHIFT). Contributions also came from the IMR Project No. 536879: Krill-dominated Ecosystem Dynamics in the Scotia Sea. A.H.H.R.'s contribution was supported by the Research Council of Norway Project No. 267416: From swarming behaviour to trophic interactions: forecasting dynamics of Antarctic krill in ecosystem hotspots using behaviour-based models (SWARM). Special thanks to Dr. Ben Raymond (Australian Antarctic Division), Dr. So Kawaguchi (Australian Antarctic Division), and Dr. Huw Griffiths (British Antarctic Survey) for jointly hunting down the elusive figure showing Antarctic krill modeled habitat suitability in high resolution.

\section{LITERATURE CITED}

Agnew DJ (1997) The CCAMLR Ecosystem Monitoring Programme. Antarct Sci 9:235-242

Atkinson A, Siegel V, Pakhomov EA, Rothery P (2004) Longterm decline in krill stock and increase in salps within the Southern Ocean. Nature 432:100-103

Atkinson A, Shreeve RS, Hirst AG, Rothery P and others (2006) Natural growth rates of Antarctic krill (Euphausia superba): II. Predictive models based on food, temperature, body length, sex and maturity stage. Limnol Oceanogr 51:973-987

Atkinson A, Siegel V, Pakhomov EA, Rothery P and others (2008) Oceanic circumpolar habitats of Antarctic krill. Mar Ecol Prog Ser 362:1-23

Atkinson A, Siegel V, Pakhomov EA, Jessopp MJ, Loeb V (2009) A re-appraisal of the total biomass and annual production of Antarctic krill. Deep Sea Res I 56:727-740

Atkinson A, Hill SL, Pakhomov EA, Siegel V and others (2017) KRILLBASE: a circumpolar database of Antarctic 
krill and salp numerical densities, 1926-2016. Earth Syst Sci Data 9:193-210

Atkinson A, Hill SL, Pakhomov EA, Siegel V and others (2019) Krill (Euphausia superba) distribution contracts southward during rapid regional warming. Nat Clim Change 9:142-147

Azaneu M, Kerr R, Mata MM, Garcia CAE (2013) Trends in the deep Southern Ocean (1958-2010): implications for Antarctic Bottom Water properties and volume export. J Geophys Res Oceans 118:4213-4227

Bargmann HE (1945) The development and life-history of adolescent and adult krill Euphausia superba. Discov Rep 23:103-176

BAS (British Antarctic Survey) (2018) Managing the fishery for Antarctic krill: a brief review of important environmental and management considerations. Science Report. https:// www.bas.ac.uk/data/our-data/publication/managing-thefishery-for-antarctic-krill-a-brief-review-of-importantenvironmental-and-management-considerations/

Bellard C, Bertelsmeier C, Leadley P, Thuiller W, Courchamp F (2012) Impacts of climate change on the future of biodiversity. Ecol Lett 15:365-377

BIOMASS (1986) Post-FIBEX acoustic workshop. BIOMASS Rep Ser 40

Brierley AS, Fernandes PG, Brandon MA, Armstrong F and others (2002) Antarctic krill under sea ice: elevated abundance in a narrow band just south of ice edge. Science 295:1890-1892

Brooks CM, Crowder LB, Österblom H, Strong AL (2020) Reaching consensus for conserving the global commons: the case of the Ross Sea, Antarctica. Conserv Lett 13:e12676

Burrows MT, Tarling G (2004) Effects of density dependence on diel vertical migration of populations of northern krill: a genetic algorithm model. Mar Ecol Prog Ser 277: 209-220

CCAMLR (1991a) Report of the Tenth Meeting of the Commission. https://www.ccamlr.org/en/system/files/e-cc-x. pdf

CCAMLR (1991b) Conservation Measure 32/X-1991. Precautionary catch limitations on Euphausia superba in Statistical Area 48. https://www.ccamlr.org/en/measure32/x-1991

CCAMLR (1992) Conservation Measure 46/XI-1992. Allocation of precautionary catch limit on Euphausia superba in Statistical Area 48 (Conservation Measure 32/X) to Statistical Subareas. https://www.ccamlr.org/en/measure-46/ xi-1992

CCAMLR (2000a) Report of the Nineteenth Meeting of the Commission. https://www.ccamlr.org/en/system/files/eCC-xix.pdf

CCAMLR (2000b) Conservation Measure 32/XIX-2000. Precautionary catch limitations on Euphausia superba in Statistical Area 48. https://www.ccamlr.org/en/measure32/xix-2000

CCAMLR (2007) Report of the Twenty-Sixth Meeting of the Commission. https://www.ccamlr.org/en/system/files/eCC-xxvi.pdf

CCAMLR (2008) Report of the Twenty-Seventh Meeting of the Commission. https://www.ccamlr.org/en/system/files/ e-cC-xxvii.pdf

CCAMLR (2009a) Report of the Twenty-Eighth Meeting of the Commission. https://www.ccamlr.org/en/system/files/ e-cC-xxviii.pdf

CCAMLR (2009b) Conservation Measure 51-07-2009. Interim distribution of the trigger level for the krill fishery in Statistical Subareas 48.1, 48.2, 48.3 and 48.4. https:// www.ccamlr.org/en/measure-51-07-2009

CCAMLR (2010) Conservation Measure 51-01-2010. Precautionary catch limitations on Euphausia superba in Statistical Subareas 48.1, 48.2, 48.3 and 48.4. https:// www.ccamlr.org/en/measure-51-01-2010

CCAMLR (2015) Krill-biology, ecology and fishing. https:// www.ccamlr.org/en/fisheries/krill-\%E2\%80\%93-biologyecology-and-fishing

CCAMLR (2016a) Report of the Thirty-Fifth Meeting of the Commission. https://www.ccamlr.org/en/system/files/eCC-Xxxv_2.pdf

CCAMLR (2016b) Conservation Measure 51-07-2016. Interim distribution of the trigger level for the krill fishery in Statistical Subareas 48.1, 48.2, 48.3 and 48.4. https://www. ccamlr.org/en/measure-51-07-2016

CCAMLR (2017) Report of the Thirty-Sixth Meeting of the Commission. https://www.ccamlr.org/en/system/files/eCC-Xxxvi_0.pdf

CCAMLR (2018) Krill Fishery Report 2018. https://www. ccamlr.org/en/system/files/00 \%20KRI48\%202018.pdf

CCAMLR (2020) Report of the Thirty-Ninth Meeting of the Commission. https://www.ccamlr.org/en/system/files/ecC-39-rep.pdf

Chambers DP (2018) Using kinetic energy measurements from altimetry to detect shifts in the positions of fronts in the Southern Ocean. Ocean Sci 14:105-116

Chapman CC (2017) New perspective on frontal variability in the Southern Ocean. J Phys Oceanogr 47:1151-1168

Christensen LB (2006) Reconstructing historical abundances of exploited marine mammals at the global scale. MSc thesis, University of British Columbia, Vancouver

Clarke A, Harris CM (2003) Polar marine ecosystems: major threats and future change. Environ Conserv 30:1-25

* Clarke A, Tyler PA (2008) Adult Antarctic krill feeding at abyssal depths. Curr Biol 18:282-285

Clarke A, Murphy EJ, Meredith MP, King JC, Peck LS, Barnes DKA, Smith RC (2007) Climate change and the marine ecosystem of the western Antarctic Peninsula. Philos Trans R Soc B 362:149-166

* Clarke A, Griffiths HJ, Barnes DKA, Meredith MP, Grant SM (2009) Spatial variation in seabed temperatures in the Southern Ocean: implications for benthic ecology and biogeography. J Geophys Res 114:G03003

Clarke LJ, Suter L, King R, Bissett A, Bestley S, Deagle BE (2021) Bacterial epibiont communities of panmictic Antarctic krill are spatially structured. Mol Ecol 30: 1042-1052

Cleary AC, Durbin EG, Cesas MC, Zhou M (2016) Winter distribution and size structure of Antarctic krill Euphausia superba populations in-shore along the West Antarctic Peninsula. Mar Ecol Prog Ser 552:115-129

Constable AJ, Nicol S, Strutton PG (2003) Southern Ocean productivity in relation to spatial and temporal variation in the physical environment. J Geophys Res 108:8079

* Constable AJ, Melbourne-Thomas J, Corney SP, Arrigo KR and others (2014) Climate change and Southern Ocean ecosystems I: how changes in physical habitats directly affect marine biota. Glob Change Biol 20: 3004-3025

Cox MJ, Candy S, de la Mare WK, Nicol S, Kawaguchi S, Gales N (2018) No evidence for a decline in the density of Antarctic krill Euphausia superba Dana, 1850, in the Southwest Atlantic sector between 1976 and 2016. J Crustac Biol 38:656-661 
Cox MJ, Candy S, de la Mare WK, Nicol S, Kawaguchi S, Gales N (2019) Clarifying trends in the density of Antarctic krill Euphausia superba Dana, 1850 in the South Atlantic. A response to Hill et al. J Crustac Biol 39:323-327

Cresswell KA, Tarling GA, Thorpe SE, Burrows MT, Wiedenmann J, Mangel M (2009) Diel vertical migration of Antarctic krill (Euphausia superba) is flexible during advection across the Scotia Sea. J Plankton Res 31: 1265-1281

Cristofari R, Liu X, Bonadonna F, Cherel Y and others (2018) Climate-driven range shifts of the king penguin in a fragmented ecosystem. Nat Clim Change 8:245-251

* Curran MAJ, van Ommen TD, Morgan VI, Phillips KL, Palmer AS (2003) Ice core evidence for Antarctic sea ice decline since the 1950s. Science 302:1203-1206

Cuzin-Roudy J (1987a) Sexual differentiation in the Antarctic krill Euphausia superba Dana (Crustacea: Euphausiacea). J Crustac Biol 7:518-524

Cuzin-Roudy J (1987b) Gonad history of the Antarctic krill Euphausia superba during its breeding season. Polar Biol $7: 237-244$

* Cuzin-Roudy J (1993) Reproductive strategies of the Mediterranean krill, Meganyctiphanes norvegica and the Antarctic krill, Euphausia superba (Crustacea: Euphausiacea). Invertebr Reprod Dev 23:105-114

Cuzin-Roudy J (2000) Seasonal reproduction, multiple spawning, and fecundity in northern krill, Meganyctiphanes norvegica and Antarctic krill, Euphausia superba. Can J Fish Aquat Sci 57:6-15

Cuzin-Roudy J, Amsler MO (1991) Ovarian development and sexual maturity staging in Antarctic krill Euphausia superba Dana (Crustacea: Euphausiacea). J Crustac Biol 11:236-249

Cuzin-Roudy J, Labat JP (1992) Early summer distribution of Antarctic krill sexual development in the Scotia-Weddell region: a multivariate approach. Polar Biol 12:65-74

Cuzin-Roudy J, Irisson JO, Penot F, Kawaguchi S, Vallet C (2014) Southern Ocean euphausiids. In: De Broyer C, Koubbi P, Griffiths HJ, Raymond B and others (eds) Biogeographic atlas of the Southern Ocean. Scientific Committee on Antarctic Research, Cambridge, p 309-320

Dahms HU, Dobretsov S, Lee JS (2011) Effects of UV radiation on marine ectotherms in polar regions. Comp Biochem Physiol C Toxicol Pharmacol 153:363-371

Daly KL (1990) Overwintering development, growth, and feeding of larval Euphausia superba in the Antarctic marginal ice zone. Limnol Oceanogr 35:1564-1576

Daly KL (1998) Physioecology of juvenile Antarctic krill (Euphausia superba) during spring in ice-covered seas. Antarct Res Ser 73:183-198

Daly KL, Macaulay MC (1991) Influence of physical and biological mesoscale dynamics on the seasonal distribution and behaviour of Euphausia superba in the Antarctic marginal ice zone. Mar Ecol Prog Ser 79:37-66

De Broyer C, Koubbi P, Griffiths HJ, Raymond B and others (eds) (2014) Biogeographic Atlas of the Southern Ocean. Scientific Committee on Antarctic Research, Cambridge

De Robertis A (2002) Size-dependent visual predation risk and the timing of vertical migration: an optimization model. Limnol Oceanogr 47:925-933

Deagle BE, Faux C, Kawaguchi S, Meyer B, Jarman SN (2015) Antarctic krill population genomics: apparent panmixia, but genome complexity and large population size muddy the water. Mol Ecol 24:4943-4959
Demer DA, Hewitt RP (1995) Bias in acoustic biomass estimates of Euphausia superba due to diel vertical migration. Deep Sea Res I 42:455-475

*Desbruyères DG, Purkey SG, McDonagh EL, Johnson GC, King BA (2016) Deep and abyssal ocean warming from 35 years of repeat hydrography. Geophys Res Lett 43: 10356-10365

* Duan Y, Liu H, Yu W, Hou Y (2016) The mean properties and variations of the Southern Hemisphere subpolar gyres estimated by Simple Ocean Data Assimilation (SODA) products. Acta Oceanol Sin 35:8-13

* Dunlap WC, Yamamoto Y (1995) Small-molecule antioxidants in marine organisms: antioxidant activity of mycosporineglycine. Comp Biochem Physiol B 112:105-114

*Ericson JA, Hellessey N, Kawaguchi S, Nicol S, Nichols PD, Hoem N, Virtue P (2018) Adult Antarctic krill proves resilient in a simulated high $\mathrm{CO}_{2}$ ocean. Commun Biol 1: 190

Everson I (ed) (2000) Krill: biology, ecology and fisheries. Blackwell Science, Oxford

Everson I (2017) Designation and management of largescale MPAs drawing on the experiences of CCAMLR. Fish Fish 18:145-159

Fabry VJ, Seibel BA, Feely RA, Orr JC (2008) Impacts of ocean acidification on marine fauna and ecosystem processes. ICES J Mar Sci 65:414-432

Fabry VJ, Langdon C, Balch WM, Dickson AG and others (2009) Present and future impacts of ocean acidification on marine ecosystems and biogeochemical cycles. Report of the Ocean Carbon and Biogeochemistry Scoping Workshop on Ocean Acidification Research, 9-11 October 2007, La Jolla, CA

Fach BA, Hofmann EE, Murphy EJ (2002) Modeling studies of Antarctic krill Euphausia superba survival during transport across the Scotia Sea. Mar Ecol Prog Ser 231: 187-203

Fach BA, Hofmann EE, Murphy EJ (2006) Transport of Antarctic krill (Euphausia superba) across the Scotia Sea. Part II: krill growth and survival. Deep Sea Res I 53:1011-1043

Farman JC, Gardiner BG, Shanklin JD (1985) Large losses of total ozone in Antarctica reveal seasonal $\mathrm{ClO}_{X} / \mathrm{NO}_{X}$ interaction. Nature 315:207-210

Feely RA, Doney SC, Cooley SR (2009) Ocean acidification: present conditions and future changes. Oceanography 22:36-47

Flores H, Atkinson A, Kawaguchi S, Krafft BA and others (2012a) Impact of climate change on Antarctic krill. Mar Ecol Prog Ser 458:1-19

F Flores H, van Franeker JA, Siegel V, Haraldsson M and others (2012b) The association of Antarctic krill Euphausia superba with the under-ice habitat. PLOS ONE 7:e31775

Foxton P (1956) The distribution and the standing crop of zooplankton in the Southern Ocean. Discov Rep 28: $191-236$

Foxton P (1966) The distribution and life history of Salpa thompsoni Foxton with observations on a related species, Salpa gerlachei. Discov Rep 34:1-116

*Freeman NM, Lovenduski NS, Gent PR (2016) Temporal variability in the Antarctic Polar Front (2002-2014). J Geophys Res Oceans 121:7263-7276

Gaten E, Tarling G, Dowse H, Kysiacou C, Rosato E (2008) Is vertical migration in Antarctic krill (Euphausia superba) influenced by an underlying circadian rhythm? J Genet $87: 473-483$ 
Gieskes WWC, Kraay GW (1990) Transmission of ultraviolet light in the Weddell Sea: report of the first measurements made in the Antarctic. Biomass Newsl 12:12-14

Gille ST (2002) Warming of the Southern Ocean since the 1950s. Science 295:1275-1277

Gille ST (2008) Decadal-scale temperature trends in the Southern Hemisphere Ocean. J Clim 21:4749-4765

* Gille ST (2014) Meridional displacement of the Antarctic Circumpolar Current. Philos Trans R Soc A 372:20130273

Godlewska M (1996) Vertical migrations of krill (Euphausia superba Dana). Pol Arch Hydrobiol 43:9-63

Gutt J, Siegel V (1994) Benthopelagic aggregations of krill (Euphausia superba) on the deeper shelf of the Weddell Sea (Antarctic). Deep Sea Res I 41:169-178

Hamner WM (1984) Aspects of schooling of Euphausia superba. J Crustac Biol 4:67-74

Hamner WM, Hamner PP (2000) Behaviour of Antarctic krill (Euphausia superba): schooling, foraging, and antipredatory behaviour. Can J Fish Aquat Sci 57(Suppl S3): 192-202

Hamner WM, Hamner PP, Strand SW, Gilmer RW (1983) Behavior of Antarctic krill, Euphausia superba: chemoreception, feeding, schooling, and molting. Science 220: 433-435

Hempel G (1985) Antarctic marine food webs. In: Siegfried WR, Condy PR, Laws RM (eds) Antarctic nutrient cycles and food webs. Springer, Berlin, p 266-270

Hewitt RP, Watkins J, Naganobu M, Sushin V and others (2004a) Biomass of Antarctic krill in the Scotia Sea in January/February 2000 and its use in revising an estimate of precautionary yield. Deep Sea Res II 51: 1215-1236

Hewitt RP, Watters G, Trathan PN, Croxall JP and others (2004b) Options for allocating the precautionary catch limit of krill among small-scale management units in the Scotia Sea. CCAMLR Sci 11:81-97

*Hill SL, Phillips T, Atkinson A (2013) Potential climate change effects on the habitat of Antarctic krill in the Weddell Quadrant of the Southern Ocean. PLOS ONE 8: e72246

Hill SL, Atkinson A, Darby C, Fielding S and others (2016) Is current management of the Antarctic krill fishery in the Atlantic sector of the Southern Ocean precautionary? CCAMLR Sci 23:31-51

Hill SL, Atkinson A, Pakhomov EA, Siegel V (2019) Evidence for a decline in the population density of Antarctic krill Euphausia superba Dana 1850, still stands: a comment on Cox et al. J Crustac Biol 39:316-322

Hofmann EE, Hüsrevoğlu YS (2003) A circumpolar modeling study of habitat control of Antarctic krill (Euphausia superba) reproductive success. Deep Sea Res II 50: 3121-3142

* Hofmann EE, Murphy EJ (2004) Advection, krill and Antarctic marine ecosystems. Antarct Sci 16:487-499

Kofmann EE, Capella JE, Ross RM, Quetin LB (1992) Models of the early life history of Euphausia superba-Part I. Time and temperature dependence during the descentascent cycle. Deep Sea Res I 39:1177-1200

Holm-Hansen O, Mitchell BG, Vernet M (1989) Ultraviolet radiation in Antarctic waters: effects on rates of primary production. Antarct J US 24:177-178

Hønneland G, Revenga L, Addison J (2020) Aker Biomarine Antarctic krill: Final Draft Report (Conformity Assessment Body: Lloyd's Register). Marine Stewardship Council, London
*Hucke-Gaete R, Osman LP, Moreno CA, Torres D (2004) Examining natural population growth from near extinction: the case of the Antarctic fur seal at the South Shetlands, Antarctica. Polar Biol 27:304-312

Huntley ME, Zhou M (2004) Influence of animals on turbulence in the sea. Mar Ecol Prog Ser 273:65-79

IPCC (Intergovernmental Panel on Climate Change) (2007) Fourth Assessment Report: climate change (AR4). Working Group II Report: impacts, adaptation and vulnerability. Cambridge University Press, Cambridge

Jacquet J, Pauly D, Ainley D, Holt S, Dayton P, Jackson J (2010) Seafood stewardship in crisis. Nature 467:28-29

* Jarman S, Elliott N, Nicol S, McMinn A, Newman S (1999) The base composition of the krill genome and its potential susceptibility to damage by UV-B. Antarct Sci 11:23-26

Jarvis T, Kelly N, Kawaguchi S, van Wijk E, Nicol S (2010) Acoustic characterization of the broad-scale distribution and abundance of Antarctic krill (Euphausia superba) off East Antarctica $\left(30-80^{\circ} \mathrm{E}\right)$ in January-March 2006. Deep Sea Res II 57:916-933

Jullion L, Naveira Garabato AC, Meredith MP, Holland PR, Courtois P, King BA (2013) Decadal freshening of the Antarctic bottom water exported from the Weddell Sea. J Clim 26:8111-8125

K Karentz D, Lutze LH (1990) Evaluation of biologically harmful ultraviolet radiation in Antarctica with a biological dosimeter designed for aquatic environments. Limnol Oceanogr 35:549-561

Karentz D, McEuen FS, Land MC, Dunlap WC (1991) Survey of mycosporine-like amino acid compounds in Antarctic marine organisms: potential protection from ultraviolet exposure. Mar Biol 108:157-166

Kawaguchi K, Ishikawa S, Matsuda O (1986) The overwintering of Antarctic krill (Euphausia superba Dana) under the coastal fast ice off the Ongul Islands in Lützow-Holm Bay, Antarctica. Mem Natl Inst Polar Res 44 (Spec Issue): 67-85

Kawaguchi S, Nicol S (2007) Learning about Antarctic krill from the fishery. Antarct Sci 19:219-230

Kawaguchi S, Nicol S (2020) Krill fishery. In: Lovrich G, Thiel M (eds) The natural history of the Crustacea. Fisheries and aquaculture, Vol 9. Oxford University Press, New York, NY, p 137-158

*Kawaguchi S, Candy SG, King R, Naganobu M, Nicol S (2006) Modelling growth of Antarctic krill. I. Growth trends with sex, length, season, and region. Mar Ecol Prog Ser 306:1-15

Kawaguchi S, King R, Meijers R, Osborn JE, Swadling KM, Ritz DA, Nicol S (2010) An experimental aquarium for observing the schooling behaviour of Antarctic krill (Euphausia superba). Deep Sea Res II 57:683-692

Kawaguchi S, Kurihara H, King R, Hale L and others (2011) Will krill fare well under Southern Ocean acidification? Biol Lett 7:288-291

Kawaguchi S, Ishida A, King R, Raymond B and others (2013a) Seawater carbonate chemistry and hatch rates of Antarctic krill (dataset associated with Kawaguchi et al. 2013b). PANGAEA, https://doi.org/10.1594/PANGAEA. 826460

K Kawaguchi S, Ishida A, King R, Raymond B and others (2013b) Risk maps for Antarctic krill under projected Southern Ocean acidification. Nat Clim Change 3:843-847

Kils U (1981) The swimming behavior, swimming performance and energy balance of Antarctic krill, Euphausia superba. Biomass Sci Ser 3:1-121 
Kim SU, Kim KY (2021) Impact of climate change on the primary production and related biogeochemical cycles in the coastal and sea ice zone of the Southern Ocean. Sci Total Environ 751:141678

Kock KH, Reid K, Croxall J, Nicol S (2007) Fisheries in the Southern Ocean: an ecosystem approach. Philos Trans R Soc B 362:2333-2349

Krafft BA, Krag LA (2015) Assessment of mortality of Antarctic krill (Euphausia superba) escaping from a trawl. Fish Res 170:102-105

Krafft BA, Skaret G, Knutsen T (2015) An Antarctic krill (Euphausia superba) hotspot - population characteristics, abundance and vertical structure explored from a krill fishing vessel. Polar Biol 38:1687-1700

Krafft BA, Krag LA, Knutsen T, Skaret G and others (2018) Summer distribution and demography of Antarctic krill (Euphausia superba) (Dana, 1852) (Euphausiacea) at the South Orkney Islands, 2011-2015. J Crus Biol 38: 682-688

Kwok R, Comiso JC (2002) Spatial patterns of variability in Antarctic surface temperature: connections to the Southern Hemisphere annular mode and the Southern oscillation. Geophys Res Lett 29:1705-1709

*Lancraft TM, Torres JJ, Hopking TL (1989) Micronekton and microzooplankton in the open waters near Antarctic ice edge zones (AMERIEZ 1983 and 1986. Polar Biol 9: 225-233

Lascara CM, Hofmann EE, Ross RM, Quetin LB (1999) Seasonal variability in the distribution of Antarctic krill, Euphausia superba, west of the Antarctic Peninsula. Deep Sea Res I 46:951-984

Latogurski VI (1979) Recognizing of independent population of Antarctic krill. Rybn Khoz (Mosc) 10:12-14 (in Russian)

Le Févre J, Legendre L, Rivkin RB (1998) Fluxes of biogenic carbon in the Southern Ocean: roles of large microphagous zooplankton. J Mar Syst 17:325-345

Levitus S, Antonov JI, Boyer TP, Stephens C (2000) Warming of the world oceans. Science 287:2225-2229

KLevitus S, Antonov JI, Boyer TP (2005) Warming of the world ocean, 1955-2003. Geophys Res Lett 32:L02604

Loeb V, Siegel V, Holm-Hansen O, Hewitt R, Fraser W, Trivelpiece W, Trivelpiece S (1997) Effects of sea-ice extent and krill or salp dominance on the Antarctic foodweb. Nature 387:897-900

Loeb VJ, Hofmann EE, Klinck JM, Holm-Hansen O, White WB (2009) ENSO and variability of the Antarctic Peninsula pelagic marine ecosystem. Antarct Sci 21:135-148

Mackintosh NA (1973) Distribution of post-larval krill in the Antarctic. Discov Rep 36:95-156

Marchant HJ (1994) Biological impacts of seasonal ozone depletion. In: Hempel G (ed) Antarctic science: global concerns. Springer, Berlin, p 95-109

Marr JWS (1962) The natural history and geography of the Antarctic krill (Euphausia superba Dana). Discov Rep 32: 33-464

Mauchline J (1980) The biology of mysids and euphausiids. Adv Mar Biol 18:1-681

Mauchline J, Fisher LR (1969) The biology of euphausiids. Adv Mar Biol 7:1-454

*Mayzaud P, Albessard E, Cuzin-Roudy J (1998) Changes in lipid composition of the Antarctic krill Euphausia superba in the Indian sector of the Antarctic Ocean: influence of geographical location, sexual maturity stage and distribution among organs. Mar Ecol Prog Ser 173: 149-162
McBride MM, Dalpadado P, Drinkwater KF, Godø OR and others (2014) Krill, climate, and contrasting future scenarios for Arctic and Antarctic fisheries. ICES J Mar Sci 71:1934-1955

McNeil BI, Matear RJ (2008) Southern Ocean acidification: a tipping point at 450-ppm atmospheric $\mathrm{CO}_{2}$. Proc Natl Acad Sci USA 105:18860-18864

Meijers AJS (2014) The Southern Ocean in the coupled model intercomparison project phase 5. Philos Trans R Soc A 372:20130296

Meijers AJS, Shuckburgh E, Bruneau N, Sallée JB, Bracegirdle TJ, Wang Z (2012) Representation of the Antarctic Circumpolar Current in the CMIP5 climate models and future changes under warming scenarios. J Geophys Res 117:C12008

Meijers AJS, Meredith MP, Murphy EJ, Chambers DP, Belchier M, Young EF (2019) The role of ocean dynamics in king penguin range estimation. Nat Clim Change 9: 120-121

* Meredith MP, King JC (2005) Rapid climate change in the ocean west of the Antarctic Peninsula during the second half of the 20th century. Geophys Res Lett 32:L19604

* Meyer B, Atkinson A, Blume B, Bathmann UV (2002) Feeding and energy budgets of Antarctic krill Euphausia superba at the onset of winter-I-Furcilia III larvae. Limnol Oceanogr 47:943-952

*Meyer B, Freier U, Grimm V, Groeneveld J and others (2017) The winter pack-ice zone provides a sheltered but foodpoor habitat for larval Antarctic krill. Nat Ecol Evol 1: 1853-1861

* Meyer B, Atkinson A, Bernard KS, Brierley AS and others (2020) Successful ecosystem-based management of Antarctic krill should address uncertainties in krill recruitment, behaviour and ecological adaptation. Commun Earth Environ 1:28

* Midorikawa T, Inoue HY, Ishii M, Sasano D and others (2012) Decreasing pH trend estimated from 35-year time series of carbonate parameters in the Pacific sector of the Southern Ocean in summer. Deep Sea Res I 61:131-139

KMontes-Hugo M, Doney SC, Ducklow HW, Fraser W, Martinson D, Stammerjohn SE, Schofield O (2009) Recent changes in phytoplankton communities associated with rapid regional climate change along the western Antarctic Peninsula. Science 323:1470-1473

Mori M, Corney SP, Melbourne-Thomas J, Klocker A, Sumner M, Constable A (2017) A biologically relevant method for considering patterns of oceanic retention in the Southern Ocean. Prog Oceanogr 159:1-12

*Morris DJ, Ward P, Clarke A (1983) Some aspects of feeding in the Antarctic krill Euphausia superba. Polar Biol 2: 21-26

*Murphy EJ, Watkins JL, Trathan PN, Reid K and others (2007) Spatial and temporal operation of the Scotia Sea ecosystem: a review of large-scale links in a krill centred food web. Philos Trans R Soc B 362:113-148

Murphy EJ, Cavanagh RD, Drinkwater KF, Grant SM and others (2016) Understanding the structure and functioning of polar pelagic ecosystems to predict the impacts of change. Proc R Soc B 283:20161646

Nemoto T, Okiyama M, Takahashi M (1985) Aspects of the roles of squid in food chains of marine Antarctic ecosystems. In: Siegfried WR, Condy PR, Laws RM (eds) Antarctic nutrient cycles and food webs. Springer, Berlin, p 415-420 
Newman SJ, Nicol S, Ritz DA, Marchant HJ (1999) Susceptibility of Antarctic krill (Euphausia superba Dana) to ultraviolet radiation. Polar Biol 22:50-55

* Newman SJ, Dunlap WC, Nicol S, Ritz D (2000) Antarctic krill (Euphausia superba) acquire a UV-absorbing mycosporine-like amino acid from dietary algae. J Exp Mar Biol Ecol 255:93-110

Newman SJ, Ritz D, Nicol S (2003) Behavioural reactions of Antarctic krill (Euphausia superba Dana) to ultraviolet and photosynthetically active radiation. J Exp Mar Biol Ecol 297:203-217

Nicol S (2006) Krill, currents, and sea ice: Euphausia superba and its changing environment. Bioscience 56: $111-120$

Nicol S (2018) The curious life of krill: a conservation story from the bottom of the world. Island Press, Washington, DC

Nicol S, Raymond B (2012) Pelagic ecosystems in the waters off East Antarctica $\left(30^{\circ} \mathrm{E}-150^{\circ} \mathrm{E}\right)$. In: Rogers AD, Johnston NM, Murphy EJ, Clarke A (eds) Antarctic ecosystems: an extreme environment in a changing world. Wiley-Blackwell, Oxford, p 243-254

Nicol S, Pauly T, Bindoff NL, Wright S and others (2000a) Ocean circulation off east Antarctica affects ecosystem structure and sea-ice extent. Nature 406:504-507

Nicol S, Constable A, Pauly T (2000b) Estimates of circumpolar Antarctic krill abundance based on recent acoustic density measurements. CCAMLR Sci 7:87-99

Nicol S, Foster J, Kawaguchi S (2012) The fishery for Antarctic krill - recent developments. Fish Fish 13:30-40

O'Brien C, Virtue P, Kawaguchi S, Nichols PD (2011) Aspects of krill growth and condition during late winter-early spring off East Antarctica $\left(110-130^{\circ}\right.$ E). Deep Sea Res II 58:1211-1221

* Orr JC, Fabry VJ, Aumont O, Bopp L and others (2005) Anthropogenic ocean acidification over the twenty-first century and its impact on calcifying organisms. Nature 437:681-686

Orr JC, Caldeira K, Fabry V, Gattuso JP and others (2009) Research priorities for understanding ocean acidification. Summary from the Second Symposium on the Ocean in a High- $\mathrm{CO}_{2}$ World. Oceanography 22:182-189

Pakhomov EA, Froneman PW, Perissinotto R (2002) Salp/ krill interactions in the Southern Ocean: spatial segregation and implications for the carbon flux. Deep Sea Res II 49:1881-1907

* Parkinson CL (2002) Trends in the length of the Southern Ocean sea-ice season, 1979-99. Ann Glaciol 34:435-440

Phleger CF, Nelson MM, Mooney BD, Nichols PD (2002) Inter-annual and between species comparison of the lipids, fatty acids and sterols of Antarctic krill from the US AMLR Elephant Island survey area. Comp Biochem Physiol B Biochem Mol Biol 131:733-747

Piñones A, Fedorov AV (2016) Projected changes of Antarctic krill habitat by the end of the 21st century. Geophys Res Lett 43:8580-8589

`Piñones A, Hofmann EE, Daly KL, Dinniman MS, Klinck JM (2013) Modeling environmental controls on the transport and fate of early life stages of Antarctic krill (Euphausia superba) on the western Antarctic Peninsula continental shelf. Deep Sea Res I 82:17-31

Pörtner HO (2012) Integrating climate-related stressor effects on marine organisms: unifying principles linking molecule to ecosystem-level changes. Mar Ecol Prog Ser 470:273-290
Press AJ, Hodgson-Johnston I, Constable AJ (2019) The principles of the Convention on the Conservation of Antarctic Marine Living Resources: why its Commission is not a regional fisheries management organisation. In: Liu N, Brooks CM, Qin T (eds) Governing marine living resources in the polar regions. Edward Elgar Publishing, Cheltenham, p 9-29

* Purkey SG, Johnson GC (2012) Global contraction of Antarctic bottom water between the 1980s and 2000s. J Clim 25:5830-5844

Quetin LB, Ross RM (1984) Depth distribution of developing Euphausia superba embryos, predicted from sinking rates. Mar Biol 79:47-53

Quetin LB, Ross RM (2001) Environmental variability and its impact on the reproductive cycle of Antarctic krill. Am Zool 41:74-89

* Quetin LB, Ross RM, Frazer TK, Amsler MO, Wyatt-Evens C, Oakes SA (2003) Growth of larval krill, Euphausia superba, in fall and winter west of the Antarctic Peninsula. Mar Biol 143:833-843

Quetin LB, Ross RM, Fritsen CH, Vernet M (2007) Ecological responses of Antarctic krill to environmental variability: Can we predict the future? Antarct Sci 19:253-266

Raskoff KA, Purcell JE, Hopcroft RR (2005) Gelatinous zooplankton of the Arctic Ocean: in situ observations under the ice. Polar Biol 28:207-217

* Rayfuse R (2019) Addressing climate change impacts in regional fisheries management organizations. Management options for high seas fisheries: making regime complexes more effective. In: Caddell R, Molenaar EJ (eds) Strengthening international fisheries law in an era of changing oceans. Hart, Oxford, p 247-268

Reilly S, Hedley S, Borberg J, Hewitt R, Thiele D, Watkins J, Naganobu M (2004) Biomass and energy transfer to baleen whales in the South Atlantic sector of the Southern Ocean. Deep Sea Res II 51:1397-1409

Reiss CS, Cossio AM, Loeb V, Demer DA (2008) Variations in the biomass of Antarctic krill (Euphausia superba) around the South Shetland Islands, 1996-2006. ICES J Mar Sci 65:497-508

* Reiss CS, Cossio A, Santora JA, Dietrich KS and others (2017) Overwinter habitat selection by Antarctic krill under varying sea-ice conditions: implications for top predators and fishery management. Mar Ecol Prog Ser 568:1-16

* Renner AHH, Thorpe SE, Heywood KJ, Murphy EJ, Watkins JL, Meredith MP (2012) Advective pathways near the tip of the Antarctic Peninsula: trends, variability and ecosystem implications. Deep Sea Res I 63:91-101

* Richardson AJ (2008) In hot water: zooplankton and climate change. ICES J Mar Sci 65:279-295

Rintoul S, Sparrow M, Meredith M, Wadley V and others (2012) The Southern Ocean observing system: initial science and implementation strategy. Scientific Committee on Antarctic Research, Cambridge

Ritz DA (2000) Is social aggregation in aquatic crustaceans a strategy to conserve energy? Can J Fish Aquat Sci 57: 59-67

Roel B, Ríos J (2020) DERIS, S.A. - Pesca Chile-Antarctic krill fishery. First Surveillance Audit Report (Conformity Assessment Body: Bureau Veritas). Marine Stewardship Council, London

Ross RM, Quetin LB (1991) Ecological physiology of larval euphausiids, Euphausia superba (Euphausiaceae). Mem Queensl Mus 31:321-333 
Ross RM, Quetin LB (2000) Reproduction in Euphausiacea. In: Everson I (ed) Krill: biology, ecology and fisheries. Fish and aquatic resources series 6. Blackwell Science, Oxford, p 150-180

Ross RM, Quetin LB, Baker KS, Vernet M, Smith RS (2000) Growth limitation in young Euphausia superba under field conditions. Limnol Oceanogr 45:31-43

Russell FS (1927) The vertical distribution of plankton in the sea. Biol Rev Camb Philos Soc 2:213-262

Ryabov AB, de Roos AM, Meyer B, Kawaguchi S, Blasius B (2017) Competition-induced starvation drives largescale population cycles in Antarctic krill. Nat Ecol Evol 1: 0177

Santa Cruz F, Ernst B, Arata JA, Parada C (2018) Spatial and temporal dynamics of the Antarctic krill fishery in fishing hotspots in the Bransfield Strait and South Shetland Islands. Fish Res 208:157-166

SC-CAMLR (1989) Report of the Eighth Meeting of the Scientific Committee. https://www.ccamlr.org/en/system/ files/e-sc-viii.pdf

SC-CAMLR (1991) Report of the Tenth Meeting of the Scientific Committee. https://www.ccamlr.org/en/system/ files/e-sc-x.pdf

SC-CAMLR (1992) Report of the Eleventh Meeting of the Scientific Committee. https://www.ccamlr.org/en/system/ files/e-sc-xi.pdf

SC-CAMLR (2002) Report of the Twenty-First Meeting of the Scientific Committee. https://www.ccamlr.org/en/ system/files/e-sc-xxi.pdf

SC-CAMLR (2003) Report of the Twenty-Second Meeting of the Scientific Committee. https://www.ccamlr.org/en/ system/files/e-sc-xxii.pdf

SC-CAMLR (2004) Report of the Twenty-Third Meeting of the Scientific Committee. https://www.ccamlr.org/en/ system/files/e-sc-xxiii.pdf

SC-CAMLR (2008) Report of the Twenty-Seventh Meeting of the Scientific Committee. https://www.ccamlr.org/en/ system/files/e-sc-xxvii.pdf

SC-CAMLR (2009) Report of the Twenty-Eighth Meeting of the Scientific Committee. https://www.ccamlr.org/en/ system/files/e-sc-xxviii.pdf

SC-CAMLR (2013) Report of the Thirty-First Meeting of the Scientific Committee. https://www.ccamlr.org/en/system/ files/e-sc-xxxi.pdf

SC-CAMLR (2016) Report of the Thirty-Fifth Meeting of the Scientific Committee. https://www.ccamlr.org/en/system/ files/e-sc-xxxv.pdf

SC-CAMLR (2018) Report of the Thirty-Seventh Meeting of the Scientific Committee. https://www.ccamlr.org/en/sccamlr-xxxvii

SC-CAMLR (2019a) Report of the Thirty-Eighth Meeting of the Scientific Committee. Preliminary version. https:// www.ccamlr.org/en/sc-camlr-38

SC-CAMLR (2019b) Report of the Working Group on Ecosystem Monitoring and Management (Concarneau, France, 24 June to 5 July 2019). https://www.ccamlr. org/en/sc-camlr-38/03

Schiermeier Q (2010) Ecologists fear Antarctic krill crisis. Nature 467:15

Schmidt K, Atkinson A, Steigenberger S, Fielding S and others (2011) Seabed foraging by Antarctic krill; implications for stock assessment, bentho-pelagic coupling and the vertical transfer of iron. Limnol Oceanogr 56:1411-1428

Schmidt K, Atkinson A, Pond DW, Ireland LC (2014) Feeding and overwintering of Antarctic krill across its major habitats: the roles of sea ice cover, water depth and phytoplankton abundance. Limnol Oceanogr 59:17-36

* Schmidtko S, Heywood KJ, Thompson AF, Aoki S (2014) Multidecadal warming of Antarctic waters. Science 346: 1227-1231

Siegel V (1987) Age and growth of Antarctic Euphausiacea (Crustacea) under natural conditions. Mar Biol 96:483-495

Siegel V (2005) Distribution and population dynamics of Euphausia superba: summary of recent findings. Polar Biol 29:1-22

Siegel V (2016) Biology and ecology of Antarctic krill. Springer International Publishing, Cham

Siegel V, Loeb V (1995) Recruitment of Antarctic krill Euphausia superba and possible causes for its variability. Mar Ecol Prog Ser 123:45-56

* Siegel V, Watkins JL (2016) Distribution, biomass and demography of Antarctic krill, Euphausia superba. In: Siegel V (ed) Biology and ecology of Antarctic krill. Advances in Polar Ecology. Springer International Publishing, Cham, p 21-100

* Silk JRD, Thorpe SE, Fielding S, Murphy EJ, Trathan PN, Watkins JL, Hill SL (2016) Environmental correlates of Antarctic krill distribution in the Scotia Sea and southern Drake Passage. ICES J Mar Sci 73:2288-2301

* Smetacek V, Nicol S (2005) Polar ocean ecosystems in a changing world. Nature 437:362-368

* Smith CR, DeMaster DJ (2008) Preface and brief synthesis for the FOODBANCS volume. Deep Sea Res II 55: 2399-2403

Smith CR, Mincks S, DeMaster DJ (2006) A synthesis of bentho-pelagic coupling on the Antarctic shelf: food banks, ecosystem inertia and global climate change. Deep Sea Res II 53:875-894

* Smith IJ, Stevens DP, Heywood KJ, Meredith MP (2010) The flow of the Antarctic Circumpolar Current over the North Scotia Ridge. Deep Sea Res I 57:14-28

Smith RC, Prézelin BB, Baker KS, Bidigare RR and others (1992) Ozone depletion: ultraviolet radiation and phytoplankton biology in Antarctic waters. Science 255:952-959

* Spiridonov V (1995) Spatial and temporal variability in reproductive timing of Antarctic krill (Euphausia superba Dana). Polar Biol 15:161-174

Stock CA, Alexander MA, Bond NA, Brander KM and others (2011) On the use of IPCC-class models to assess the impact of climate on living marine resources. Prog Oceanogr 88:1-27

Stokke OS, Vidas D (1996) The effectiveness of CCAMLR. In: Stokke OS, Vidas D (eds) Governing the Antarctic: the effectiveness and legitimacy of the Antarctic Treaty System. Cambridge University Press, Cambridge, p 120-151

Sumby J, Haward M, Fulton EA, Pecl GT (2021) Hot fish: the response to climate change by regional fisheries bodies. Mar Policy 123:104284

Swart NC, Gille ST, Fyfe JC, Gillett NP (2018) Recent Southern Ocean warming and freshening driven by greenhouse gas emissions and ozone depletion. Nat Geosci 11: 836-841

Sykora-Bodie ST, Morrison TH (2019) Drivers of consensusbased decision-making in international environmental regimes: lessons from the Southern Ocean. Aquat Conserv 29:2147-2161

Taki K, Yabuki T, Noiri Y, Hayashi T, Naganobu M (2008) Horizontal and vertical distribution and demography of euphausiids in the Ross Sea and its adjacent waters in 2004/2005. Polar Biol 31:1343-1356 
Tarling GA, Thorpe SE (2014) Instantaneous movement of krill swarms in the Antarctic Circumpolar Current. Limnol Oceanogr 59:872-886

Tarling GA, Shreeve RS, Hirst AG, Atkinson A, Pond DW, Murphy EJ, Watkins JL (2006) Natural growth rates in Antarctic krill (Euphausia superba): I. Improving methodology and predicting intermolt period. Limnol Oceanogr 51:959-972

* Thorpe SE, Heywood KJ, Stevens DP, Brandon MA (2004) Tracking passive drifters in a high resolution ocean model: implications for interannual variability of larval krill transport to South Georgia. Deep Sea Res I 51:909-920

Thorpe SE, Murphy EJ, Watkins JL (2007) Circumpolar connections between Antarctic krill (Euphausia superba Dana) populations: investigating the roles of ocean and sea ice transport. Deep Sea Res I 54:792-810

Trathan PN, Agnew D (2010) Climate change and the Antarctic marine ecosystem: an essay on management implications. Antarct Sci 22:387-398

Trathan PN, Brierley AS, Brandon MA, Bone DG and others (2003) Oceanographic variability and changes in Antarctic krill (Euphausia superba) abundance at South Georgia. Fish Oceanogr 12:569-583

*Tulloch VJD, Plagányi ÉE, Brown C, Richardson AJ, Matear R (2019) Future recovery of baleen whales is imperiled by climate change. Glob Change Biol 25: 1263-1281

United Nations (1980) Convention on the Conservation of Antarctic Marine Living Resources (Canberra, 20 May 1980). United Nations Treaty Series Vol 1329, No 22301. UN, New York, NY. https://treaties.un.org/doc/Publi cation/UNTS/Volume \% 201329/v1329.pdf

Veytia D, Corney S, Meiners KM, Kawaguchi S, Murphy EJ, Bestley S (2020) Circumpolar projections of Antarctic krill growth potential. Nat Clim Change 10:568-575

Walther GR, Post E, Convey P, Menzel A and others (2002) Ecological responses to recent climate change. Nature 416:389-395

Watkins JL, Reid K, Ramn D, Zhao XY and others (2016) The use of fishing vessels to provide acoustic data on the distribution and abundance of Antarctic krill and other pelagic species. Fish Res 178:93-100

Editorial responsibility: Antonio Bode, A Coruña, Spain

Reviewed by: 2 anonymous referees
Watters GM, Hill SL, Hinke JT, Matthews J, Reid K (2013) Decision-making for ecosystem-based management: evaluating options for a krill fishery with an ecosystem dynamics model. Ecol Appl 23:710-725

*Weydmann A, Søreide JE, Kwasniewski S, Widdicombe S (2012) Influence of $\mathrm{CO}_{2}$-induced acidification on the reproduction of a key Arctic copepod Calanus glacialis. J Exp Mar Biol Ecol 428:39-42

Whitehouse MJ, Meredith MP, Rothery P, Atkinson A, Ward P, Korb RE (2008) Rapid warming of the ocean around South Georgia, Southern Ocean, during the 20th century: forcings, characteristics and implications for lower trophic levels. Deep Sea Res I 55:1218-1228

Wiedenmann J (2010) Implications of climate change for Antarctic krill and their cetacean predators. PhD dissertation, University of California, Santa Cruz, CA

*Wiedenmann J, Cresswell K, Mangel M (2008) Temperature-dependent growth of Antarctic krill: predictions for a changing climate from a cohort model. Mar Ecol Prog Ser 358:191-202

* Wiedenmann J, Cresswell KA, Mangel M (2009) Connecting krill recruitment and sea ice. Limnol Oceanogr 54: 799-811

Williamson CE, Zepp RG, Lucas RM, Madronich S and others (2014) Solar ultraviolet radiation in a changing climate. Nat Clim Change 4:434-441

WMO (2011) Scientific Assessment of Ozone Depletion: 2010. Global Ozone Research and Monitoring Project, Rep 52. World Meteorological Organization https://ozone.unep. org/sites/default/files/2019-05/00-SAP-2010-Assementreport.pdf

* Young EF, Thorpe SE, Banglawala N, Murphy EJ (2014) Variability in transport pathways on and around the South Georgia shelf, Southern Ocean: implications for recruitment and retention. J Geophys Res Oceans 119: $241-252$

* Youngs MK, Thompson AF, Flexas MM, Heywood KJ (2015) Weddell Sea export pathways from surface drifters. J Phys Oceanogr 45:1068-1085

Zhou M, Dorland RD (2004) Aggregation and vertical migration behavior of Euphausia superba. Deep Sea Res II 51: 2119-2137

Submitted: June 12, 2020

Accepted: March 22, 2021

Proofs received from author(s): June 9, 2021 